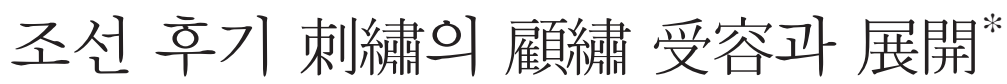

$$
\text { 양 수 정** }
$$

I . 머리말

II. 명청대 顧繡와 그 양상

III. 조선 후기 자수의 고수 수용과 전개

IV. 맺음말

\section{I. 머리말}

조선 후기는 양란(兩亂)과 명·청대 교체기를 거치면서 규범과 풍습, 경제 등에 있어 전반적인 변화가 도모되었다. 문예도 탈속과 심미적인 문인문화가 성행하면서 정통성을 담은 남종화법이 학습되었고, 묘사의 핍진감과 실물감의 증진을 위해 서양화법도 수용하였다. 또한 진경산수화와 풍속화가 유행하면서 조선의 실체를 시각화한 정형 이미지가 구축되었 으며, 그 향유층이 크게 확장되었다. 경화세족이나 사족 그리고 여항문인을 포함한 부를 가진 중인계층까지도 문인문화의 취향을 공동으로 소유하였으며, 이를 고급문화로 특별히

* 본 논고는 '2020년 신진학자학술대회(2020. 10. 17)'에서 발표된 내용을 보완하여 정리한 글로, 연구의 완성을 위해 여러 심도있는 코멘트를 주신 심사위원 선생님들께 깊이 감사드린다.

** 문화재청 문화재감정위원

1 홍선표, 「朝鮮 後期 繪畫의 창작태도와 표현방법론」,「朝鮮 後期 繪畫의 새 경향」,『朝鮮時代繪畫史論」(문예 출판사, 1999), pp. 255-323.

(C) This is an open-access article distributed under the terms of the Creative Commons Attribution Non-Commercial License (http:// creativecommons. org/licenses/by-nc/4.0/), which permits unrestricted non-commercial use, distribution, and reproduction in any medium, provided the original work is properly cited. 
여기는 풍습도 생기게 되었다. 그리하여 시서화의 행위는 문인취향을, 각종 골동을 비롯한 기이한 물건의 소유는 한거(閑居)의 삶을, 감상용 자수그림의 소유는 특권층의 고아한 취향을 대변하는 것으로 인식하였다.

자수도 한양을 중심으로 도시문화가 성장하고 문예 성숙이 주도됨에 따라 왕실 문예를 궁양(宮樣)으로 보고 그 유행을 뒤따르는 시정풍속이 생겨, 기존 계서적(階序的), 의장적 (意匠的) 소용(所用)에 중점을 두었던 역할이 크게 변하게 되었다. 기존 왕실과 권문가 일부의 감상용으로 제작되던 자수그림은 수장의 취미가 반영되면서 회화와 더불어 수집의 대상이 되었고, 이를 소장, 감상, 감평하는 대상이 되었다. 또한 남과 다른 차별화된 물품을 향유 하면서, 누가, 어디서 만들었는지를 따지는 감평 태도와 소비 형태도 확산되었다. ${ }^{3}$ 이처럼 높아진 감상안을 충족하기 위해서 전문 제작가와 공방이 출현하였으며 이들로 인해서 각종 자수기법들의 소멸과 생성 과정이 반복되었고, 다양한 도상과 구입 능력에 따른 차등있는 자수그림병풍이 제작되면서 사회 각층의 수요에 부응하였다. ${ }^{4}$

조선시대에 자수 혹은 감상용 자수그림의 제작에 관한 기록은 여성의 여공(女功) 내용을 담고 있는 애사문을 포함한 다양한 문헌에서조차 신사임당(申師任堂, 1504 1551)을 제외하 고는 거의 찾아보기 어렵고, 17 세기에 들어서야 관련 기록들이 등장하기 시작한다. ${ }^{5}$ 왕실행 보로 공식적인 기록은 인조의 모친인 인헌왕후(仁獻王后, 1578 1626)의 '어수(御繡)' 행적 이었으며, ${ }^{6}$ 감상용 자수그림 존재는 정혜옹주(貞惠翁主, 1584 1638)의 전칭작 자수그림 〈연당원앙도(蓮塘鴐鷯圖)〉(견본자수, $42.7 \times 40.7 \mathrm{~cm}$, 간송미술관 $(『$ 간송문화』 65 , fig.48)를

2 자수그림이라는 용어는 시대적, 문예적 의미를 지닌 도상을 '자수라는 행위'를 통해서 이루어진 일체의 그림 을 칭한 것이다. 자수라는 용어의 등장은 고려부터 조선시대 사가의 애사문을 통해 3-4회에 불과하며 이것 또한 침선(針線)인지, 봉침(縫針)인지 불명확한 용도였으며, 『선화봉사고려도경(宣和奉使高麗圖經)」의 수도 (繝圖)를 제외하고 정확하게 감상용으로 제작된 정황은 찾아볼 수 없었다. 감상용 자수그림을 칭하는 용어로

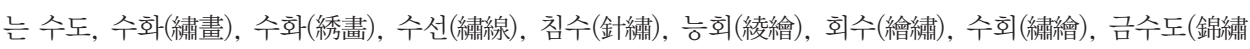
圖), 궁선수(宮線啸) 등 다양한 용어가 문헌에 출전하였으나 주제어로 삼기에는 무리가 있었다. 따라서 17세 기에 본격적으로 회화의 도상을 자수로 시수(施鹔)한 것들이 등장하기에, 자수그림이라는 용어로 대신하였 음을 밝힌다. 추후 깊은 연구를 통해 적합한 용어가 합의된다면 그 용어를 사용하고자 한다.

3 안대회, 「조선 후기 취미생활과 문화현상」, 『韓國文化」60(2012), p. 68.

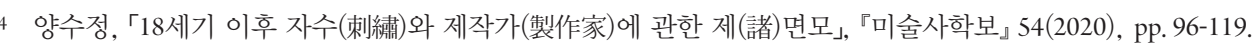

5 양수정, 「조선시대 자수그림 연구-16 18세기를 중심으로」(이화여자대학교 박사학위논문, 2016 (a)), pp. 310323.

$6 『$ 列聖御製』16, 「仁穆王后御筆 仁獻王后親紼 仁祖大王畫贊 并小序」(서울대학교규장각, 『列聖御覽』2(서울대 학교규장각, 영인본, 2002), p. 101). 
통해 살필 수 있다. 또한 기존 명으로부터 사여(賜與)되던 자수흉배가 본격적으로 사가에서 제작된 것이 17 세기에 들어서 시작된 만큼, ${ }^{8}$ 감상용 자수그림의 제작은 17 세기에서도 왕실의 어람용과 같은 치정적(治政的) 의장(意匠)이 목적이어서, 권문가에서는 쉽게 접할 수 없는 생소한 것이었다고 할 수 있다. 다만 그들에게 선물로 입수된 명대 감상용 자수그림은 완물과 청완(淸玩)의 대상이 되어 전가진완(傳家珍玩)으로 보장되기도 하였다. ${ }^{9}$

18 세기 중엽이 되면 생경한 대상이던 감상용 자수그림은 차차 지배층의 신문물에 대한 동경과 호기심에 의해서 소장의 품목이 될 정도로 각광을 받게 되었는데, ${ }^{10}$ 그 제작은 대부분 전문 공방에서 이루어졌다. 그것은 기존 수첩(繣帖)의 제작을 집안 여공으로 받아들이던 분위기 ${ }^{11}$ 대신 베도 못 짜고 밥도 못 짓는 한양 부인의 행태가 만연되어, 교화가 쇠퇴하면서 풍습이 어지러운 세태가 있었기 때문이었다. 예를 들어 규방의 가르침을 가르치질 않아 화양(華樣)의 가법(假法, 머리장식)이라든가, 화장과 같은 치장에 관심이 높아졌고, 침선을 위한 바느질과 수놓는 재주 정도를 가르치거나, 혹은 힘든 일이기에 아예 가르치지 않아 여성의 여공과 여기(餘技)마저 변화되었고, 예법을 하찮게 여기는 탈규범화가 진행되고 있었다. ${ }^{12}$

본 연구는 국립중앙박물관 소장의 〈전(傳)정명공주(貞明公主, 1603 1685)작자수〉 (덕수 6030) $)^{13}$ 와 미상 〈(자수)고사인물도〉(덕수 4331)가 명·청대 강남지방 명수(名繡)인

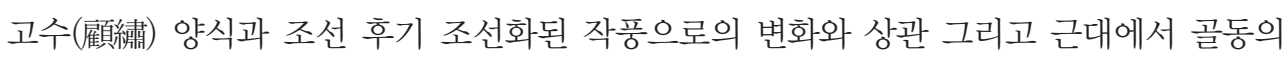
의미가 부여되는 시대성도 담고 있어, 조선 후기 감상용 자수그림의 제작과 유행에 있어

7 이 자수그림〈연지원당도〉는 전칭작이지만 만지교(滿池嬌)풍의 연지수금도 양식으로 도상이나 기법에 이어 古式을 담고 있다. 더욱이 그 작풍이 동시대 유물인 인목대비(仁穆大妃, 1584 1632)의『금광명최승왕경(金 光明最勝王經) $\lrcorner$ 의〈사경 표지수〉(조선, $1622,34.6 \times 12 \mathrm{~cm}$, 동국대학교박물관)와 유사하여 이 시기의 유물로 추정하였다.

8 정혜란, 「중국흥배와 한국흥배의 비교고찰」『고문화』57(한국대학박물관협회), p. 215.

9 李瀷, 『星湖全集』56, 「題咙」, [跋家傳紼長」; 李元翼, 『梧里先生文集』1, 「詩」, [錦障花草帖 六首并敍], 李埈, 『荅石先生文集」14, 「跋」, [梧里李相公花草障後跋], 『荅石先生文集』3, 「詩」, [次韻題梧里相國刺紼花草].

10 황정연, 「18세기 경화사족의 서화수장과 예술취향-유만주와 『흠영 『, 『내일을 여는 역사』40(2010), pp. 160175 .

11 양수정, 「조선 17세기 䋿占의 문예사적 가치」, 『한국민화」13(2020), pp. 26-30.

12 尹鳳九, 〈孺人朴氏 $\left(1705\right.$ ? 1732) 墓誌〉, p. 87, 蔡之洪, 「孺人金氏哀辭」, p. 153, 이경하 역주, ${ }^{\circledR} 18$ 세기 여성생 활사 자료집』2(보고사, 2010); 李䋨, 〈從妹孺人李氏(1710 1734)墓誌〉, p. 62, 李德惁,「婦儀」, pp. 427-434, 서경희 역주, 『18세기 여성생활사 자료집』6 (보고사, 2010).

13 이 유물은 입수 후 유물카드에 전정명공주작자수(덕수 6030)로 기록되어 전하지만, 본 연구를 위해 〈고사인 물도>로 명칭하여 진행코자 한다. 
유의미한 상관을 살필 수 있다고 보고 이를 정리하고자 한다. 고수는 명대 가정(嘉靖, 1522 1566)연간 고씨 집안에서 제작된 감상용 자수그림을 칭하는 것으로, 청대에도 고수라 불리면서 크게 유행한 유파이다. 조선 후기가 되면 고수는 청조(淸朝)에 대한 우호적인 분위기 속에서 접할 수 있었던 중국의 다양한 지방수들 중 하나로 사료된다. 이미 조선 17세기 에서도 왕실과 종실 및 권문가를 중심으로 고수가 감상되고 유사하게 제작되었을 가능성은 선행연구를 통해 제기된 바 있다. ${ }^{14}$

우리는 대부분 18 세기 후반 이후에 제작된 다수의 자수유물들이 전하는 가운데, 그나마 수작(秀作)에 중점된 관점이 조선 시대의 자수사를 대표하고 있으며, 그 탁월한 자수 솜씨에 강한 자긍심이 존재하고 있는 것도 사실이다. 그러나 자수는 고대부터 가장 선진의 기술로서 각 국가의 의장 역할로 대표성을 가져왔고, 외교 의례상 최고의 것들이 상호 소통되면서 각국에 서로 영향을 미쳐 왔다는 것은 연구사적으로 간과되어 왔다고 할 수 있다. 따라서 본 연구의 목적은 조선 후·말기 조선적인 특색을 갖추게 되는 자수그림의 정형에는 다각적인 시각의 접근이 필요하다는 의견을 담론화하고, 추후 연구 주제인 중국 산동(山東) 노수 (魯絤)와 조선 자수와의 상관에 관한 논의와도 연결할 수 있어, 조선 후기 작풍에 대한 다양 한 담론을 제기하는 하나의 과정으로 삼고자 함에 있다.

\section{II. 명청대 顧繡와 그 양상}

\section{1. 고수의 등장과 유행}

고수는 명(明) 가정(嘉靖, 1522 1566)연간 진사였던 고명세(高明世)의 장자(長子) 고회해(顧匯海)의 처인 무씨(繆氏,? ?)로부터 비롯된다. ${ }^{15}$ 고씨 가문은 무씨의 탁월한 자수

14 양수정, 「조선 17세기 자수그림의 전승과 이행」『미술사학보』48(2017), pp. 49-51.

15 무씨(繆氏, ? ?)에 대해 전하는 기록이 거의 없었는데, 최근 정리된 자료가 있어 잠시 살펴보고자 한다. 무씨 는 이름이 액(液)이고 소주인(蘇州人)이었다. 어릴 적 전굉가(田宏家)에 기식했는데 그 집안 딸인 전유(田瑜) 가 수를 배우고 나중에 궁에 들어가자 그를 대신하여 수를 놓아서 궁에 보냈다고 하는데 후대 무씨자수가 ‘內院에 전하고 있음'을 알 수 있었다고 한다. 고가(顧家)에 들어와서 집에 소장하고 있던 송원 명가(名家)의 자화(字畫)와 봉안된 불상신조(佛像神㵯)로 예술적 감각과 시야를 넓혔으며, 또한 고명세의 훈도 아래 집안 여성들이 단청서화를 잘 그렸는데, 인물, 산, 화훼 등 살아있는 듯이 자수를 잘했다고 한다. (樓耀福, ‘女中神 
솜씨로 인해서 명성을 얻기 시작했는데, 고명세가 상해에서 '노향원(露香園)'을 건조(建造) 하였기 때문에, 세상 사람들은 그 집안의 자수를 '노향원고수' 혹은 '고씨노향원수'라고 칭하였으며 또는 '노향원수', '고수’라고 약칭하였다. ${ }^{16}$ 고수는 무씨의 딸 고난옥(顧蘭玉, ? ? $)^{17}$ 과 고회해의 조카인 고수잠(顧壽潛)의 처 한희맹(韓希孟, ? ?), 고회해의 첩(妾) 장래 (張來)에게 전수되면서 17세기 전반부터 전성기를 맞이하게 되었다. 명 숭정(崇禎, 1628 1644)년간 증수(增修)된 『송강부지(松江府志)』에 의하면 '고수는 화조를 도드라지게 제작하고, 향낭(香囊)에 인물을 만들었는데 각화처럼 정교하였으며 다른 군(郡)에는 없는 것이었다(顧繡方作花鳥, 香囊做人物, 刻畫精巧, 為他郡所未有...)'라고 기록되었다. 또한 노향원에서 제작되던 감상용 자수그림은 바늘로 붓을 대신하여 수인지 그림인지 분별하기 어려울 정도의 정교한 재현을 했기 때문에 ‘화수(畫繡)', '수화(繡畫)'라는 칭송을 받았다. 고수는 명대 한희맹의 극소수 진작을 포함해서 전해지는 대부분의 청대 고수 자수그림을 칭한다. 청대에는 이러한 양식이 강남 상해를 중심으로 주변 민가에까지 파생되었고, 이후 소수(蘇繩), 상수(湘繡), 촉수(蜀繡), 월수(粤繡) 등 강남 지방들의 자수 제작과 유파의 발전에도 큰 영향을 미쳤다.

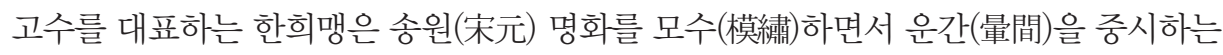
평수(本繡)의 여러 파생 기법들을 발전시키면서 고수를 더욱 유명하게 만들었는데, 이에 관해서는 한희맹의 부군인 고수잠의 기록을 통해 알 수 있다. 고수잠은 동기창(董其昌, 1555 1636)으로부터 시와 그림을 배워 뛰어난 실력을 갖춘 제자이기도 했으며, 고수 집안 사람답게 '수불주인(繝佛主人)'을 별호로 삼았다. 그는 부인인 한희맹이 방고(倣古)의 영향을 받아, 그림의 이치를 자수 기예 속에 융합시켜 화훼를 묘사하길 잘하였고, 특히 송원의 명적을 모수한 화책(畫册)《송원명적책(宋元名跡册)》(1634)을 장정한 후, 동기창의 찬(讚)을 받았던 특별한 내력을 기록하기도 하였다. ${ }^{18}$ 당시 문예방면에 영향력이 컸던 동기창은 다음과

針: 顧綉’, http://www.ifuun.com/a201801209205145/)

16 滿洲國立博物館, 『纂組英華」「解說」(東京座右寶刊行會發行, 1935), p. 45. 명 가정 38년(1559) 진사 고명세가 상해 구무지(九亩地) 노향원로에 정원을 축조할 때 연못을 파다가 하나의 돌을 얻었는데 원대의 조맹부가 손 수 새긴 “露香池” 세 글자가 새겨져 있어, 이것으로 정원의 이름을 삼았다.; 趙豊, 『中國絲綢通史」(蘇州大學校 出版社, 2005), p. 434.

17 주계검은 ‘顧會海妾蘭玉”과 ‘張來妻顧氏’으로 기록(『女紅傳征略」)하였으나, 최근에 많은 자료가 정리되면서 顧蘭玉得繆氏라고 하여 무씨의 딸은 고난옥이고, 장래는 고회해의 첩으로 알려져 있다. (https://baike.baidu. $\mathrm{hk}($ 검색어, 明代顧繣 $)$ )

18 滿洲國立博物館, 앞의 책(1935), 「解說」; “내 아내 한희맹은 특별히 고심을 다하여 항상 그 지나침에 비웃음 
같이 찬사하였다.

‘宋人의 수는 침선이 바늘과 실의 운용이 세밀하여 융(䋐)의 한두 가닥의 실에 그치는 데도 머리카락처럼 가는 바늘을 사용하여 설색(채색)이 정묘하고 광채가 눈이 부실 정도이다. 산수는 원근을 분별(구분)하는 운치가 있고 누각은 깊고 그윽한 체재를 얻고 있으며 인물은 가까운 곳을 올려다보는 것과 먼 곳을 바라보는 것이 생동하는 정취가 갖추어져 있고 화조는 여유롭게 지저귀는 자태를 극진하게 표현했다. 좋은 작품(佳作)은 그림보다도 더 뛰어나다. 멀리서 바라보면 3가지 운치가 느껴지고 十指春風할 정도이니 어찌 이러한 경 지에 이르렀는가...? 『균헌청비록(笏軒淸秘錄)』

이러한 평은 고수가 지배계층을 비롯하여 세간의 관심을 받게 하였으며, 감상용 자수 그림의 격 또한 격상되어 고수의 전성기를 이끌게 되었다고 판단할 수 있다.

당시 한희맹 이외 고수로 이름을 얻었던 이는 앞서 언급한 고난옥으로 24세 때 과부로 수절하다가, 가업이 기울자 장막을 세워 여자 제자를 교수하면서 30년 동안 집안 비수(秘繡) 였던 기예 '고수'를 밖으로 전하였으며, 특히 인물 자수그림에 이름이 높았다고 한다. ${ }^{20}$ 또한 고씨 집안 자손인 고정평(顧廷評)의 가비(家婢)가 명성이 높았는데, 그의 명에 의해서 수를 놓았다고 한다. 걸작으로 〈정침도(停金十圖)〉를 남겼으며 유양(維揚)의 대고(大賈) 간망(媳望)이 한왕(韓王, ? BC 196)의 〈연환(連環)〉과 주방(周昉, ? ?)의〈미인도(美人圖)〉를 이것과 바꿨다고 전하고 있어, 그 솜씨가 상당히 훌륭했을 것으로 여겨진다. ${ }^{21}$

을 샀다. 갑술년 봄에 송원명적을 널리 찾아서 8 가지를 임모하였는데 하나하나 수로 완성하여 그것을 모아 책으로 만들었다. 보는 사람들은 혀를 놀려 감탄하고 손으로 춤추지 않는 이가 없었다. 일찍이 알거나 보지 못했던 바를 보고 정교함을 다해 기교를 운용하면서 자나 깨나 경영하여 이미 수년의 고심과 노력을 다하였 던 것이다. 스승 동기창(사백)이 보고서 마음으로 기꺼이 칭찬하면서 나에게 '기술이 이와 같은 경지에까지 이르렀는가?'하면서 물을 정도였다. 나는 이 질문에 부응하여 삼가 대답할 도리가 없어 '추울 때나 더울 때나 비바람 쳐 날씨가 어수선할 때 혹은 너무 지나치게 춥고 더울 때나 기후가 조건이 안 좋을 때는 종사하지 않 았고 종종 날이 개고 해가 드러나 새들이 꽃향기를 기뻐할 때 눈앞의 영활한 기운을 섭취할 때만 오나라(소 주, 항주)의 비단에다가 자수를 놓았습니다'라고 하니 동기창은 더욱 감탄하면서 '사람의 인력으로 되는 것 이 아니다'라도 여겼다."

19 滿洲國立博物館, 앞의 책(1935), 「解說」, 董其昌의 撰文. “宋人之紼, 針線細密, 用䋐止一二絲, 用針如發細 者, 為之設色精妙光彩射目。山水分遠近之趣, 樓閣待深遂之體, 人物具瞻酐生生動之情, 花鳥極綽約愌唼之態, 佳者較畫更勝, 望之三趣悉備, 十指春風, 蓋至此乎.'

20 滿洲國立博物館, 위의 책(1935), pp. 45-48, 朱啟鈴, 『存素堂絲繣錄」.

21 滿洲國立博物館, 위의 책(1935), p. 17. 
현재 청대 고수작으로 전하는 다수의 〈고사인물도〉(Table 1)는 일단 각 고사에 맞춰 다양한 도상을 수본으로 구성하는 능력과 이를 재현하는 뛰어난 자수 묘사가 특징이라고 할 수 있다. 즉 비기(祕技)로 전해오는 자수기법들과 회수를 통해 그림처럼 보일 만큼 특색을 이루고 있는 것이 고수라고 정의할 수 있다. 또한 재차 모수나 방수의 방식을 통해 교본처럼 적극 활용되면서 기예를 습득하는 전승 교육의 방식으로 인해, 그 양식이 널리 유행했던 것도 특징이다.

이처럼 고수는 한희맹 이후 중국 전역에 상당한 영향력을 미쳤고, 그 명성이 일세를 풍미하게 되었지만, 일간에는 호가(豪家)에 있는 뛰어난 고수의 작품에 제멋대로 제목을 자수하기도 하고, 선물로 증답(贈答)에 사용하는 일도 있었으며, 민가 여성이 고씨의 인기 (印記)를 모방하는 경우도 있었다고 한다. 또한 청대 시속(市俗)에서는 노향원 물건이라고

〈Table 1〉 청대 고수 신선도와 고사인물도, Images of Daoist Immortals and Narrative Themes of the Gu's embroidrey in Qing dynasty

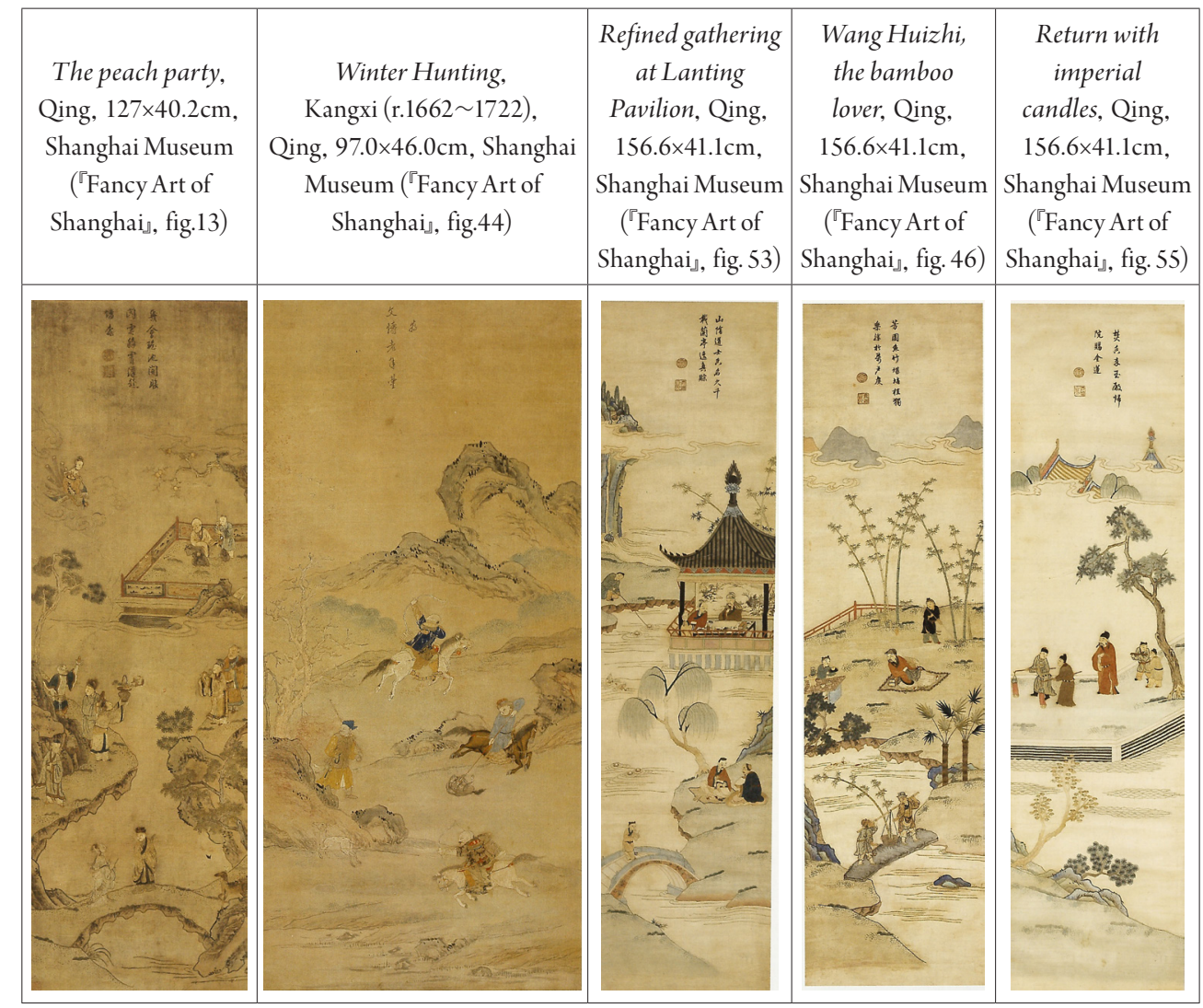


속이는 것이 하도 많아서 허리를 구부려서 주울 정도로, ${ }^{22}$ 고금명화를 본떠 제작한 고수풍의 감상용 자수그림이 꾸준히 성행하였고, 그 모수작들이 다시 모수되는 과정으로, 도상들이 서로 짜깁기되어 제작된 모수작들도 다수 전하면서 시장에 등장했던 것으로 판단된다.

청대에는 '백리(百里)의 땅에 가난한 여자가 없다'고 할 정도로, 고수의 비법을 배워 생업으로 삼은 많은 부녀자들이 일정한 규모를 형성하고 있었다. 당시 고수를 선호한 많은 달관(達官), 현환(顯宦), 부상(富商)들이 다투어 고가로 진품을 수장하여서 고수의 가치가 상당히 높았지만, 고수는 제작에 있어서 고품질을 위한 공교함이 특징이었기 때문에, 제약 된 조건이 많았으므로, 보급과 계승을 하는 데 어려움이 있어서 청대 후·말기로 이어지면 그 명성만큼의 좋은 작품이 제작되지는 못하였다. ${ }^{23}$

\section{2. 고수의 특징과 양상}

고수의 두드러진 특징은 모수, 회수, 간색운용과 다양한 침법 사용 등 크게 3 가지로 나눌 수 있다. $\left.{ }^{24} 1\right)$ 우선 회화나 자수의 원화를 선택하여 앞 사람의 명적을 모수(摸繍)하는 방법이다. 명말 노향원에서 나온 한희맹의 화첩 《송원명적책(宋元名跡册)(Fig. 1)은 당시

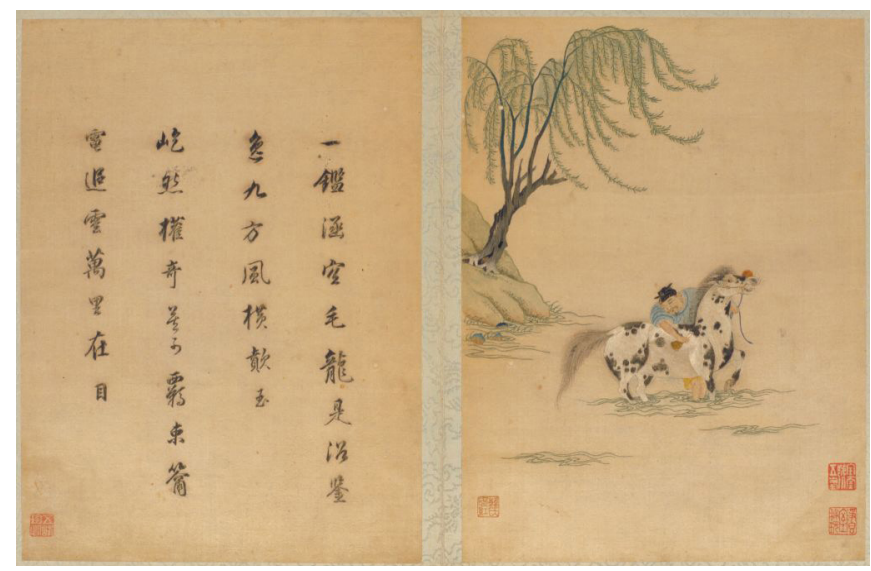

Fig. 1. 한희맹, 〈洗馬圖〉, Han Ximeng, Washing a horse, 《Copies of Song and Yuan classical paintings》 Eight album leaves, Ming dynasty, 33.4× $24.5 \mathrm{~cm}$, In the collection of Palace Museum ( ${ }^{\circledR}$ Fancy Art of Shanghai $₫$, p. 28)

22 朱啟鈴, 앞의 책, 滿洲國立博物館, 앞의 책(1935).

23 https://baike.baidu.hk(검색어, 明代顧繡).

24 양수정, 앞의 글(2016 (a), pp. 174-182. 
출간된 화보를 중심으로 모수한 것으로, 제발도 첨해 화첩 장정의 형식을 따랐다.

또한 한희맹은 송원의 명화 중 황전(黃筌, ? 965)의 《오대후촉황전장춘화조책(五代後 蜀黃鉒長春花鳥册)》중 〈다화영모(茶花翎毛)〉(Fig. 2)에서 새의 도상과 이를 모수한 송대 자수그림《송수황전화화조(宋繡黃筌畫花鳥)》중 〈부용취조(芙蓉采鳥)〉(Fig. 3)의 부용을 모본으로 삼아〈부용비조도(芙容翡鳥圖)〉(Fig. 4)를 제작 하기도 하였다. 당시 고수는 집안에 소장하던 명화 나 화보류를 통해 도상을 습득하여 제작하였기에 이런 고수 화첩은 ‘회화를 능가한다’라는 인식으로 ‘화수’, ‘수화’라 칭송되면서, 강남 명가(名家)나 부상 남성들에게는 감상용으로 고급 취향의 역할을, 명가 여성들에게는 자수본의 역할을 담당하였는 데, 이렇게 제작된 독특한 자수를 규각수(閨閣繡) 라고 칭하였다. ${ }^{25}$ 청대 고수는 한희맹 작품 또는

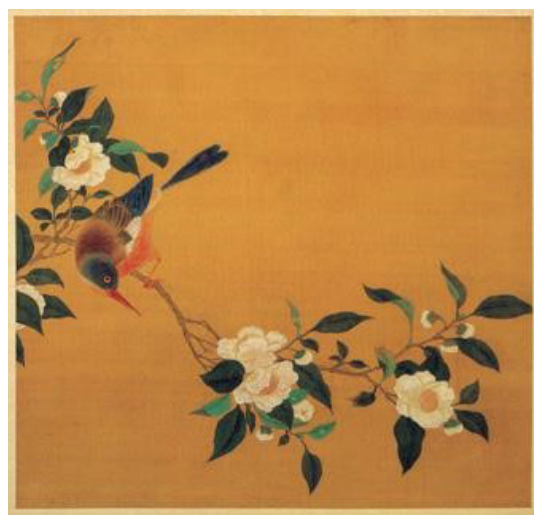

Fig. 2. 〈茶花领毛〉, Camellia with kingfisher, 《An album of the bird-and-flower painting by Huang Quan》

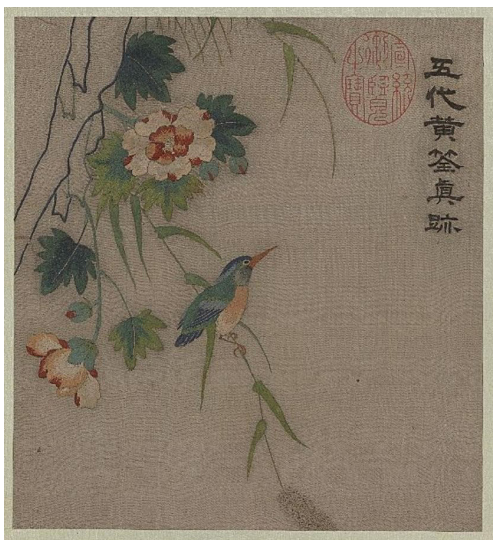

Fig. 3. 작자미상, 〈芙蓉萃鳥〉, Anonymous, Cottonrose and kingfisher, 《An album of Embroidered painting that reproduces Huang Quan's painting》, 23.1 ×21.1cm, National Palace Museum of Taipei (www. npm.gov.tw)

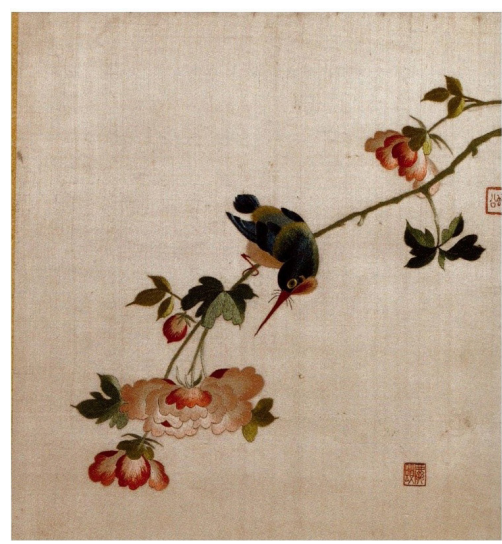

Fig. 4. 한희맹, 〈芙容翡鳥圖〉, Han Ximeng, Cottonrose and kingfisher, 《Miscellaneous album $》$, Eight album leaves, $25.9 \times 24.1 \mathrm{~cm}$, Liaoning Provincial Museum $\left({ }^{\circledR}\right.$ Fancy Art of Shanghai $₫$, fig. 16)

25 單國强, 「導言-筆墨趣味與織繡藝術」『織繡書畫』(2005), p. 17.; 趙豊, 앞의 책(2005), p. 434. 
여하의 고수 화풍을 그대로 모수하거나 화보를 모수하는 제작 방법을 지속하는데, 당시 '방고'의 풍조를 따라 익히는 교습법을 유지하였다고 볼 수 있다. 청대 고수의 이런 여파는 아마 조선 후기 이래 자수의 유행과 화풍에도 영향을 주었다고 추정된다. 예를 들어 17세기 에 들어서 본격적으로 자수흉배가 제작되었는데 원래는 명대의 것을 그대로 따르는 '의양 제조(依樣製造)'가 원칙이었으나, 18 세기 초가 되면, 일부 사가에서 제작한 흥배는 『십죽재 화보(十竹齋畫譜)』라든가『개자원화전(芥子園畫傳)』과 같은 화보의 특정 도상을 개인 취향 처럼 선택하기도 하였다. ${ }^{26}$ 또한 조선 후기에는 신사임당의 '초충도'가 수본이 되어, 유사 도상의 자수그림 병풍들이 각기 다른 시기와 자수기법으로 제작되어 여러 점 전하게 되는데, 이러한 풍조의 유입으로 신사임당의 명성에 의해 여성의 부덕인 현모양처상이 재현되는 사가의 자수 교육과 여공이 존재했을 것으로 사료된다. ${ }^{27}$

고수의 특징 중 또 하나는 2) 송대 회수(繪繡) 기법의 재현이다. 회수는 자수와 회화 기법의 결합으로, 먼저 화본을 필묵과 담채로 처리하고, 그 위에 다시 침법을 사용하거나 또는 자수된 도상 위에 먹으로 보필(補筆)을 하는 것이다. 원래 회수는 송대 황제의 어람을 위해 제작되던 회화를 격사 (緙絲)로 재현, 보장하면서 등 장한 기법이다. 즉 남송의 심자 번(沈子蕃, ? ?)의 격사그림 〈화조축(花鳥軸)〉(Fig. 5)에서 볼 수 있듯이 새의 배나 깃털 안쪽 부위에 절충된 보채(補 彩)와 보묵(補墨)(Fig. 5-1)의 흔적을 살필 수 있는데 직조로 회화를 재현하다 보니 공교함 이 부족했던 격사그림의 결점 을 보완하기 위한 것이었다. 그러나 초창기 노향원 시대에 고수가 활용한 회수는 〈종규
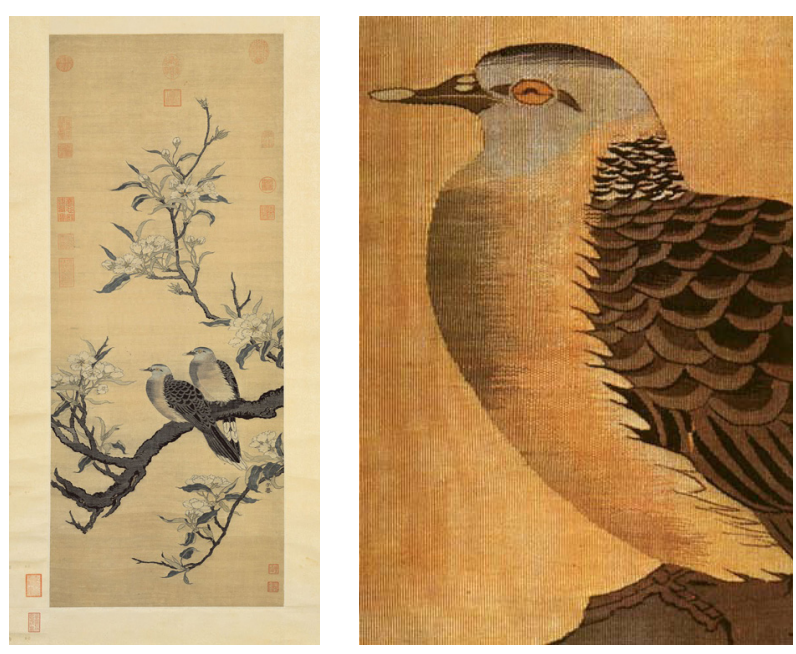

(Left) Fig. 5. 沈子蕃, 〈花鳥軸〉, Shen Zifan, Birds and Flowers, Song dynasty, colored silk tapestry, $95.7 \times 38.5 \mathrm{~cm}$ ( ${ }^{\circledR}$ Flight of Fragrance at a Fingertip』, fig. 2)

(Right) Fig. 5-1. 세부, Detail

26 양수정, 앞의 글(2017), pp. 53-54.

27 양수정, 앞의 글(2020), pp. 21-22. 
상축(鍾道象軸)〉(Fig. 6)에서 보이는 인물의 윤곽선을 자수하고 훈염된 회화 도상을 그대로 남기는 양식(Fig. 6-1, Fig. 6-2)으로 특화되었다.

그러나 한희맹의 《송원명적책》 중 〈세마도(洗馬圖)〉(Fig. 1)의 세부(Fig. 7)와〈미화산수도 (米畫山水圖) $\rangle$ (Fig. 8, 붉은 원)를 보면, 회수가 송대처럼 자수 위에 보채, 보묵하는 양식으로 전환하였다. 반면 청대 고수에 이르면 전체적으로 선염된 밑그림의 윤곽선과 특정 도상에만
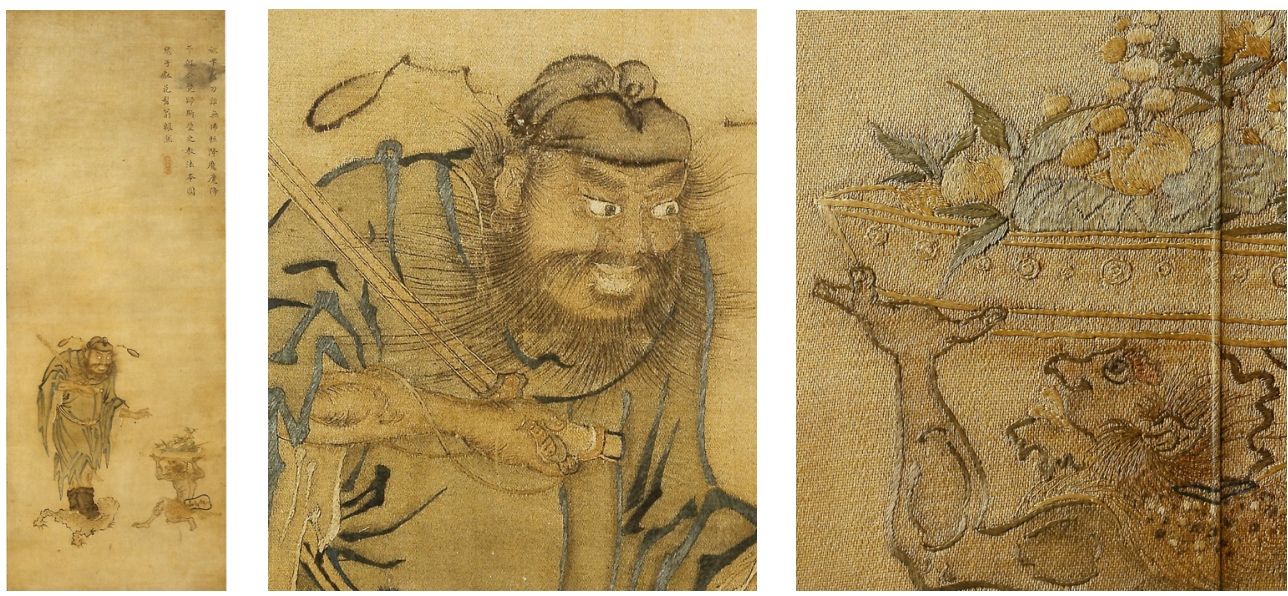

(Left) Fig. 6. 노향원수, 〈鍾道象軸〉, Xiangyuan's embroidery, Zhong Kui, Ming dynasty, Shanghai Museum (『Fancy Art of Shanghai $₫$, p. 78)

(Center) Fig. 6-1. 세부, Detail

(Right) Fig. 6-2. 세부, Detail
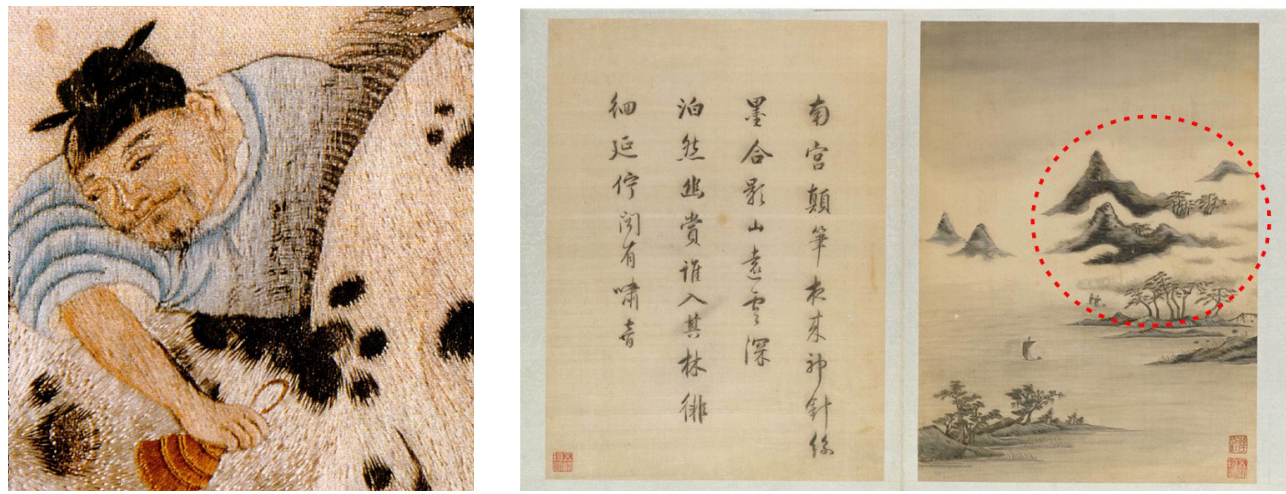

(Left) Fig. 7. 〈洗馬圖〉세부, Detail of Washing a horse

(Right) Fig. 8. 한희맹, 〈米畫山水圖〉, Han Ximeng, Landscape by Mi Fu, 《Copies of Song and Yuan classical paintings》 Eight album leaves, Ming dynasty, $33.0 \times 24.0 \mathrm{~cm}$, In the collection of Palace Museum( $\left({ }^{\circledR}\right.$ Fancy Art of Shanghai $₫$, p. 30) 
자수를 하고, 그 외에는 선염을 그대로 남기는 고수의 초창기 방식으로 다시 변화하였다. 청대 고수가 사용한 회수는 문인이 감상하는데 회화적 감상감을 높이기 위해서 필수적으로 사용한 중요한 기법 중의 하나이기도 했지만, 이러한 작풍은 작품을 분절 후 개장하는 데 용이하게 사용되기도 하였다. 가령 조선 왕 숙종도 고수풍으로 보이는 고사인물도 자수 그림을 어람(御覽)한 후 회수로 추정되는 부분에 자수를 첨하게 한 뒤 장자(障子)로 개장 (改裝)을 명한 사례가 있으며, ${ }^{28}$ 현재 전하는 전인헌왕후작 자수그림 〈신선도〉(덕수 5698, $148.3 \times 45.0 \mathrm{~cm}$ )도 분절된 개장을 거친 유물이기도 하다. ${ }^{29}$ 그러다 보니 가경연간(嘉慶年間, 1795 1820) 이후에 제작된 고수는 자수보다는 그림이 주(主)가 되는 양상으로 변용되어서, 예전의 명성만 유지되기에 이르렀다고 한다. ${ }^{30}$

마지막으로는 3) 간색(間色)이 운용되고 다양한 침법이 개발되었다. 고수는 물상의 층차가 풍부한 색채의 효과를 표현하기 위하여, 간색[중간색]으로 채사를 혼용한 운간을 통해 사실적 재현을 묘사하거나, 보색으로 채색하여 물상의 생동감을 부여하였다. 『찬조영화 (纂組英華)』(1935)에서 “명수(明繡)에서 채사로 수를 놓은 비단에는 대체로 송수(宋繡)에서는 보이지 않았던 정색 외의 중간색의 실이 있었다." 라고 한 것처럼 이런 간색의 사용은 기존 기법 상의 변화 또한 가져오게 되었다. 즉 송대〈송 서포도(松鼠葡萄)〉(Fig. 9)의 운간법을 재현한 한희맹의〈송서포도(松鼠葡萄)〉(Fig. 10)를 보면 수로(水路)가 감춰지는 푼사를 주로 사용 하였는데, 실을 갈라 쓰는 벽사(辟絲)와 간색을 적극 활용한 섬침(摻針, 또는 수화침(擻和針), 현재 우리나라 자련수)을 활용하여 사실성을 극대화한 것(Fig. 10-1)을 볼 수 있다.

이처럼 고수는 바늘로 붓을 대신하여 그림 보다 더 그림같이 정교하고 섬세한 침법들이

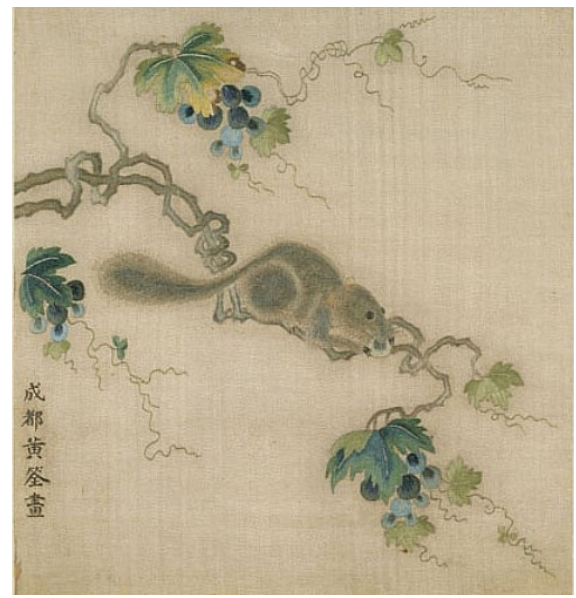

Fig. 9. 작자미상, 〈松鼠葡萄〉, Anonymous, Squirrels and grapes, 《An album of Embroidered painting that reproduces Huang Quan's painting》, $23.1 \times 21.1 \mathrm{~cm}$, National Palace Museum of Taipei (www.npm.gov.tw)

28 서울대학교 규장각, 앞의 책(영인본, 2002), p. 364.

29 양수정, 「傳 仁獻王后의 자수그림 〈신선도〉 연구」, 『동악미술사학』20(2016, (b), pp. 60-61.

30 單國强, 앞의 글(2005), p. 18. 

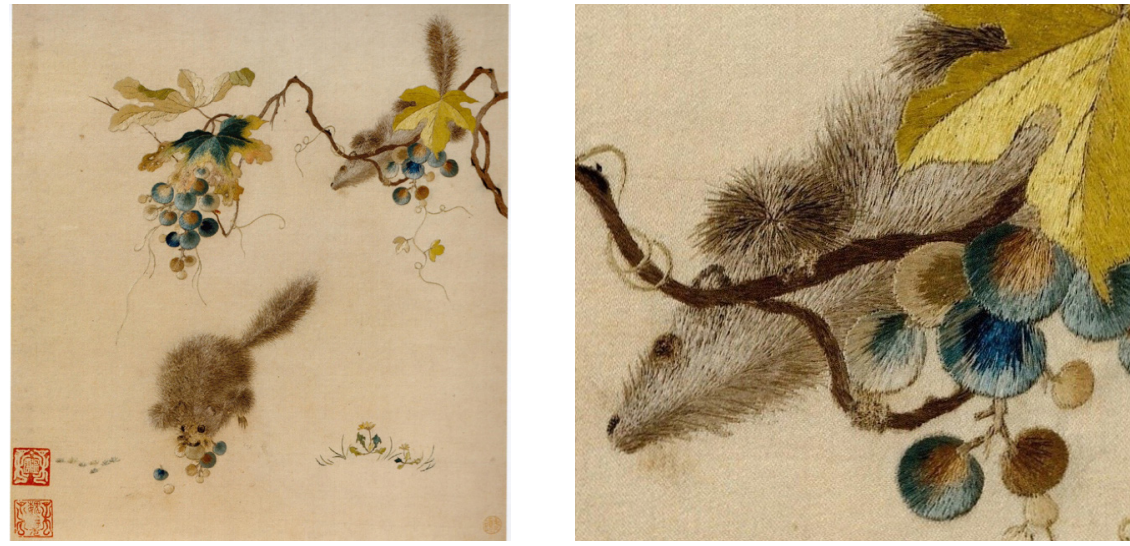

(Left) Fig. 10. 한희맹, 〈松鼠葡萄〉, Han Ximeng, Squirrels and grapes, 《Miscellaneous album》, Ten album leaves, Ming dynasty, $28.7 \times 26.8 \mathrm{~cm}$, In the collection of the Shanghai Museum ( ${ }^{\circledR}$ Fancy Art of Shanghai $₫$, p. 44)

(Right) Fig. 10-1. 세부, Detail

사용되면서, 송대 화풍의 시적 서정성을 재현하였고, 원체풍의 황실 양식을 소장할 수 있는 기회도 되었기에, 동기창을 비롯한 문인사대부들에게 자연스럽게 호응을 얻게 되었다고 판단된다. 이외 청대 고수에 이르면 〈삼성도(三星圖)〉와 같은 고사인물도의 의습(Fig. 11,

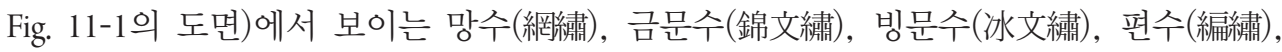
차색수(借色紼), 각린침(刻麟針) 등과 같은 특수 침법(장식수)도 운용하여 표현력이 증강되 었고, ${ }^{31}$ 이런 기법들은 감상용 자수그림을 더욱 사실성 강한 채색화처럼 보이게 하는 보완
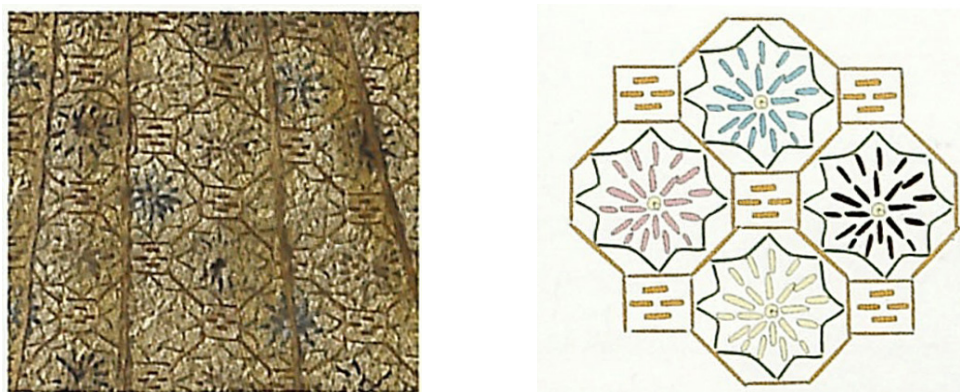

(Left) Fig. 11. 〈三星圖〉, The three immortals, detail, Qing dynasty, $126 \times 45.0 \mathrm{~cm}$, In the collection of the Shanghai Museum ( ${ }^{\circledR}$ Fancy Art of Shanghai』, p. 92)

(Right) Fig. 11-1. 錦文繡세부, Brocade embroidery, detail (『Fancy Art of Shanghai」, p. 213)

31 上海博物館 工藝研究部, 『海上錦紼』(上海博物館, 2007), pp. 207-214. 
역할을 하였다.

이로써 고수는 한희맹이 회화 6법에 깊이 통달하였고, 멀리 당송시대 발수(髮繡)의 정통을 이어받아 그 유범(遺範)인 송수를 부흥시켜 고법을 계승하면서, 명청 시대의 두 자수를 연결하는 역할을 담당했다고 사료된다. 그리고 고금명인들의 서화를 그대로 본떠 수를 놓으면서 특별히 마음에 깨우친 바가 있었으며, 침법도 위에서 열거한 것처럼 독보적인 경지에 도달하게 되었다. 이러한 수법들은 고씨 집안에 비기로 전수되어 청대에도 높은 명성을 유지하는 근거가 되었다. 청대 후기가 되면 고수는 남성들이 제작가로 대부분 참여하게 되고, 자수의 범위보다는 그림의 범위가 더 많이 대체되는 경향이 짙어 옛 명성을 잇지 못하게 되었다. 그러나 뒷장에서 좀 더 언급하겠지만, 근대기에 자수가 여성 교육과 경제 부흥의 대상 으로 동아시아에서 집중적으로 교육되는 가운데, 기존 문예 지향의 여공이자 수장의 대상 이었던 자수그림은 1930 년대가 되면 이익 실현 수단으로 골동수집의 대상이 되었고, 고수도 수집, 전시되면서 명품의 타이틀을 재 부여받게 된 것으로 보인다. 당시 서울남(徐蔚南, 1900 1952)이 편찬한『고수고(顧繡考)』(1937)에서 “고수의 그 쪼갠 실은 머리카락보다 더 가늘었고, 바늘은 터럭처럼 가늘었다. 색을 배합할 때도 비전(秘傳)이 있었다. 그러므로 물을 들여 문양을 만들 수 있었는데, 그 영모와 화훼는 조물주의 솜씨를 교묘하게 빼앗을 뿐만 아니라, 산수와 인물도 핍진하여 생동함이 드러나지 않음이 없었다.”2라고 기록되어 있는 것으로 보아, 고수는 오랫동안 감상되면서 숭상받았던 유파였음을 알 수 있다.

\section{III. 조선 후기 자수의 顧繡 수용과 전개}

\section{1. 조선 후기 자수 소용과 고수의 수용}

조선은 양란 이후 중국의 사치풍습과 절일풍습의 유입에 따라 풍속이 변하고 있었으며, 생전에 보지 못한 사치품들까지 입수되고 있었다..$^{33}$ 권문가 이상의(李向毅, 1560 1624)와

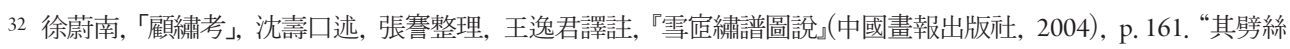
細過於髮, 而針如毫, 配色則有秘傳, 故能點染成文, 不特毣花卉巧奪天工, 而山水人物無不逼省活現”.

33 李暨 著, 『(國譯)松窩雜記」(回想社, 2000); 『承政院日記』33, 仁祖 9年(1631), 7月 8日(庚辰); 양수정, 「조선 
이원익(李元翼, 1547 1634)의 집안에도 중국 고위관료가 선물로 보낸 감상용 자수그림을 소장하였으며, 김육(金堉, 1580 1658) 역시 사절(1637) 중 연경에서 시수(施繡)된 '세화 (歲畫)'로 추정되는 수화(繡畫)를 선물로 받기도 하였다. ${ }^{34}$ 이 시기 왕실 제작의 사례로는 인목 대비의 『불설아미타경(佛說阿彌陀經)』(1621, $6.5 \times 19.8 \mathrm{~cm}$, 호암미술관(『韓畫文化』, fig. 157))과 『금광명최승왕경』의 〈사경 표지수〉 그리고 인조의 고모인 정혜옹주의 전칭작 자수그림 〈연당원앙도〉가 전하고 있다. 또한 인조의 어머니인 인헌왕후가 선조의 어람용으로 추정 할 수 있는 능양군의 그림 4폭을 수놓기도 하였다. 이러한 인헌왕후의 어수(御繡) 행보는 감상용보다는 치정적 의장이 목적이어서, 문사적(文事的)인 것에 가까웠을 것으로 사료된다. 그리고 현재 국립중앙박물관에는 인헌왕후의 전칭작 〈춘유방초도(春遊芳草圖)〉(덕수 2504, $160 \times 44.6 \mathrm{~cm})$, 〈산시청람도 $($ 山市晴嵐圖)〉(덕수 $2903,179.6 \times 46.3 \mathrm{~cm}$ )와 〈신선도〉인 3 점과 정명공주의 전칭작이 전하고 있고, 이 중 〈신선도〉는 고수 양식과 직접 관련이 있었다.

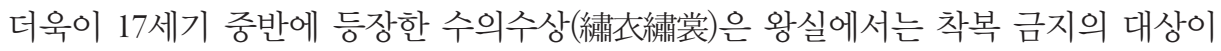
었지만, ${ }^{35} 18$ 세기 전반까지 권문가에서 유행하던 '갖춤 일괄'이었다. 심익창(沈㿽昌, 1652 1725)의 배위(配位) 성산이씨(1651 1671) 〈화조문자수스란치마9폭>(1671년 이전)의 전개도(Fig. 12)에서 볼 수 있듯이 조선 중기 화원들이 그렸다고 추정되는 감상용 화조도 도상에 자연스러운 운간을 위한 자수기법이 사용되면서, 지배층의 계서적 소용과 문예적 취향을 충족시키고 있었다. 이들은 보공(補空)이나 수의(壽衣) 형태로 왕실가의 매장 유물로 발굴된 바 있어 그 현상을 확인할 수 있으며, 자수에 대한 인식이 점차 세속화, 고급화되는 단계를 거치고 있었음을 말해준다.

또한 당시 조선 왕실에는 명말 유민 궁녀 4인이 명대 황실 유습을 전하고 있었는데, 왕실 풍습과 의례에 큰 영향을 미치고 있었다. 특히 이들 중 굴저(屈姐, 1623 1697)는 강남 소주 출신의 양가 여인으로, 숭정제(崇禎帝, r.1627 1644)의 생모인 효순유태후(孝純劉太后) 의 시녀이자, 숭정제의 황후 주황후(周皇后)의 궁녀이기도 해서, 황실 소장의 고수 존재를 알거나 감상도 했을 것으로 추정된다. 그리고 노수로 유명한 산동출신의 궁녀 최희저(崔回姐,

17세기 자수그림의 移行에 관한 試論 - 節日胸背를 중심으로」, 『동악미술사학』 23(2018), pp. 3-25.

34 주 9)참조; 金埥,『潛谷遺稿』14, 「錄」, [朝京日録], 丁丑年(1637), 1月11日.

35 정재륜, 강주진 역, 『東平尉公私聞見錄」(양영각, 1985), p. 164. 효종(孝宗, 1619 1659)과 여동생인 숙휘공주

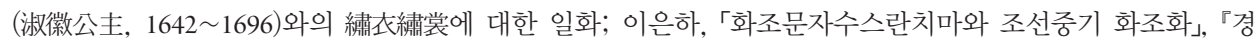
기명가 기증 출토복식 명품전, 조선의 옷매무새 III : 이승에서의 마지막 치장」(경기도박물관, 2011), pp. 96102; 양수정, 앞의 글(2017), pp. 44-45. 

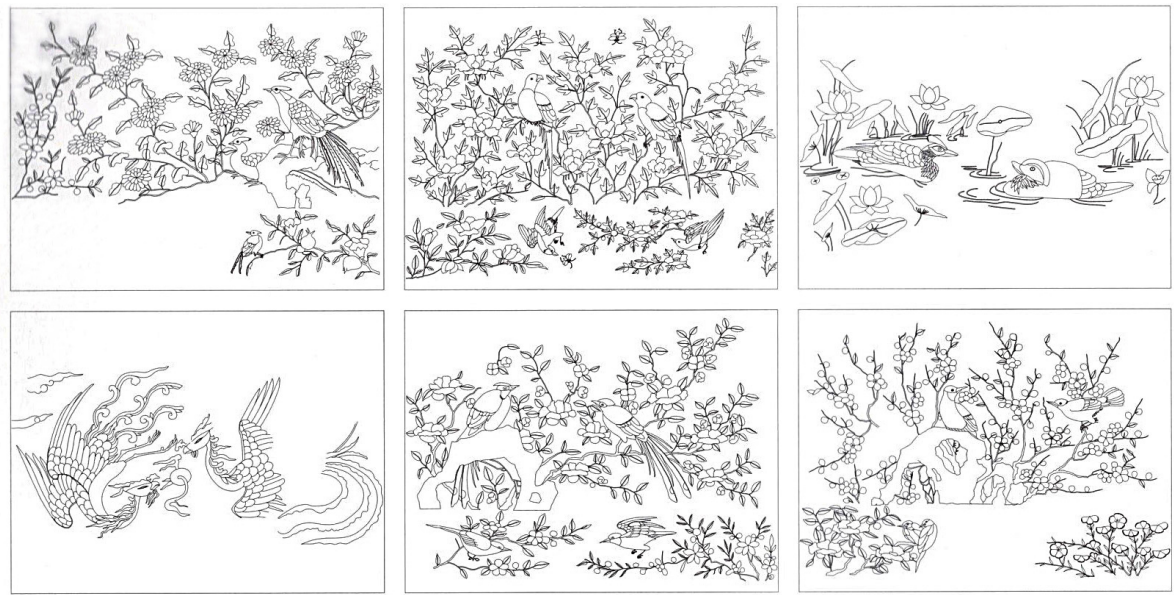

Fig. 12. 성산이씨 〈화조문자수스란치마〉의 전개도, Drawings of Embroidered flowers and birds Skirt-full, belongs to A lady who Seongsan Lee Clan, $46 \times 354 \times 50 \sim 60 \mathrm{~cm}\left({ }^{『}\right.$ The Essential Art of Costum in Joseon Dynasty:Selections from the Donated Collection : The Last Dressing in this World, fig. 14)

1626 1705)와 유저(柔姐, ? 1680)가 자수와 그림에도 능했다고 전한다. ${ }^{36}$ 따라서 이들 궁녀 들에 의해서 명대 황실의 자수 유풍(遺風)이 직접 전승될 수 있었다고 사료된다. 예를 들어 1656년 동평위(東本尉) 정재륜(鄭載崙, 1648 1723)과 숙정공주(淑靜公主, 1646 1668)와의 혼례에서 군부인과 3 명의 공주들만이 처음으로 봉황흉배를 가슴에 달게 되었는데, 이것은 1658 년 송준길(宋浚吉, 1606 1672)이 간언한 교묘한 형상과 특이한 제도로 볼 수 있는 것 으로, 명대 황궁의 의장 양식으로 추정된다. ${ }^{37} 18$ 세기 전반이 되면 이 봉황흥배는 조선 사가 및 민가 혼례에까지 유행하는 의장이 되었다. ${ }^{38}$

그리고 숙종은 여러 차례 감상용 자수그림을 어람한 적이 있었는데, 1706 1707년 사이에 진상된 〈무안왕(武安王)이 적토마를 타고 청룡도를 들고 있는 자수그림〉을 어람 후 자수를 더하여〈승적토도(乘赤免圖)〉와〈천리독행도(千里獨行圖)〉의 가리개로 개장해 두기를 명 하기도 하였다. ${ }^{39}$ 이 사례는 청 강희(康熙, r.1662 1722) 연간에 제작된〈Table 1〉의 두 번째

\footnotetext{
36 정재륜, 강주진 역, 앞의 책(1985), p. 162, pp. 329-330.

37 정재륜, 강주진 역, 위의 책(1985), p. 162, 宋浚吉, 「同春堂集續集」 8 , 「附錄三」, ‘年譜”, [戊戌(1658) (崇禎)31年 (孝宗 9), 先生 53歲 9月 1日.

38 정재륜, 강주진 역, 위의 책(1985), p. 147.

39 서울대학교규장각, 앞의 책(영인본, 2002), p. 364.
} 
고수작인 〈위렵도축(圍獵圖軸)〉이 전하는 만큼, 동시대의 고수작이 조선 왕실로 유입되어 감상되다가 자수가 첨해져 보장된 경우라고 볼 수 있다. 이러한 상관은 현재 남아 있는 여러 자수그림〈호렵도(胡獵圖)〉 병풍 중 2첩 병풍으로 전하는 〈호렵도〉(Fig. 13)에서 보이는 之자 구도라든가, 고수였다면 회수된 부분에 자수를 시수한 점, 자리수와 자련수와 같은 평수와 이음수, 장식수가 정형화(定型化)된 기법으로 사용한 점(Fig. 13-1) 등 조선 후기 자수의 전형 적인 양식으로 등장하게 되었다고 제시해 볼 수 있다.

이외 국립중앙박물관 소장의 숙종어제 〈서왕모도(西王母圖)〉 $(144.5 \times 50.3 \mathrm{~cm})$ 도 한희맹의 작품〈팔선경수괘병(八仙慶壽掛屏)〉(12폭, 명, 견본자수, $66.3 \sim 6 \times 48.1 \sim 5 \mathrm{~cm}$, 대북고궁 박물원) 중 〈서왕모도(西王母圖)〉와 강희연간 제작의 고수 풍의〈자수취소경곡도축(刺繡 吹簫慶曲圖軸) $\rangle(187 \times 47 \mathrm{~cm}$, 北京古宮博物院(『織繡書畫』, p.87))의 구도가 조합되어 있다. 그러나 이 〈서왕모도〉는 숙종의 어제가 시수되었지만, 17,18 세기 왕실본으로 보기에는 당시 유행하던 수의수상이라든가, 자수흉배와의 재현 수준과 솜씨와도 괴리가 있어 보여, 후대에
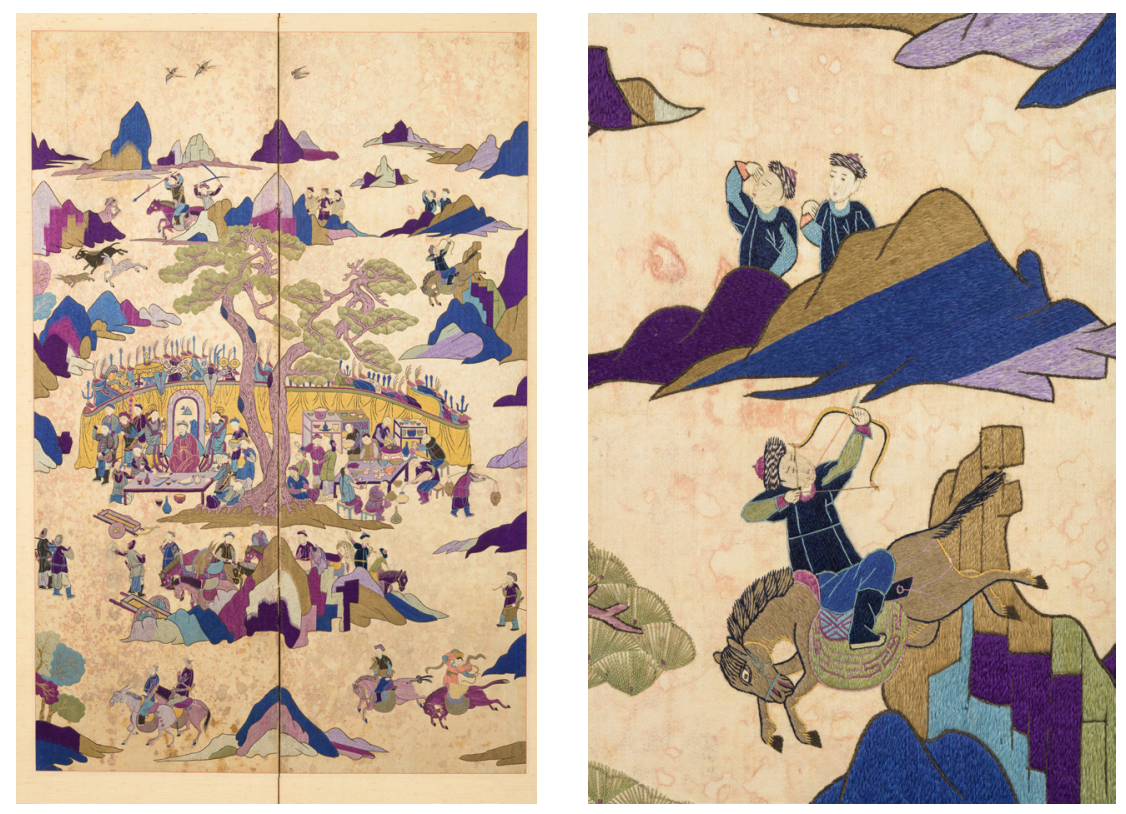

(Left) Fig. 13. 〈호렵도〉, Anonymous, King and Hunters, Two-panel screens, Embroidery on silk, $122.5 \times 40.0 \mathrm{~cm}$, Seoul Museum of Craft Art ( ${ }^{\circledR}$ Voyage to the World of Korean Embroidery』, p. 64 $)^{40}$

(Right) Fig. 13-1. 세부, Detail

40 유물 이미지 사용을 허락해주신 서울공예박물관측에 감사드린다. 
재모수된 것으로 추정해 볼 수 있다. ${ }^{41}$ 따라서 이런 숙종의 사례로 보다시피, 고수는 왕실가 에서 이미 감상용으로, 제작에 있어서는 교육용으로 사용되었을 것이고, 왕실(가) 중심으로 인식, 소장되었던 고수는 점차 조선 후기 사회로 서서히 유입되었다고 사료된다. 또한 조선 후기에는 자수의 가치와 소용이 점차 확대되면서 왕실 자수소용 중 하나였던 화첩, 고첩, 법첩 등의 표지를 자수로 의장하던 수첩이 사가에서도 제작되어 감상되었고, 공주와 옹주의 대례복인 자수된 활옷[闊衣]이 섭성(攝盛 $)^{42}$ 되는 등 계서적 용도의 자수가 사가와 민가에서 는 완물과 청완의 대상이 되기 시작하였다.

조선 사가에서 고수와 같은 감상용 자수그림을 인식한 시기는 기록상 18 세기 전반 무렵 으로 판단되는데, 1712년 북경 연행에서 김창업(金昌業, 1658 1722)이 보았던 여인이 수 놓은 〈학 그림〉이 첫 접촉으로 추정된다. 당시 중국에서는 고수가 거듭 모수되면서 가짜가 등장하고 있던 시기였긴 하나, '상당히 정묘했다'는 기록으로 보아한하희맹의 자수그림화첩 《화훼영모주수책(花卉翎毛走獸册)》(『海上錦繡』, fig.17)이『고씨화보(顧氏畫譜)』와『삼재도회 (三才圖會)』에서〈산호(山虎)〉, 〈서봉(瑞鳳)〉, 〈운룡(雲龍)〉, 〈모란(牧丹)〉 등을 모수했던 자수그림을 재모수한 고수풍의 자수그림일 가능성도 있다. 그리고 조선 고관이라도 감상용 자수그림을 소장, 감상한다는 것이 일반적인 일도 아니었고, 한희맹을 위시한 고수 집안의 전성기 자수그림이 워낙 고가였기 때문에, 진작이었다면 실제 구입은 쉽지 않았을 것이다. 그러다가 18 세기 후반이 되면 유만주(俞晚柱, 1755 1788)가 감상(1783)했던 곡병서화 114 점 중에는 자수그림이 포함되기도 하고, ${ }^{44}$ 이덕무(李德惁, 1741 1793), 성해응(成海)應, 1760 1839)의 저술에서도 다양한 중국 출신의 자수명인들의 이름과 내력도 확인할 수 있어, 그 시기가 되면 조선 사가에도 다양한 자수유파들의 작품이 소장되고 감상되었을 것이고, 거기 에는 고수도 포함되었다고 볼 수 있다. ${ }^{45}$

실례로 현재 국립중앙박물관에 소장된 미상의 〈고사인물도〉(덕수 4331)(Fig. 14) ${ }^{46}$ 를 통해서도 조선 후기 사가에서 고수를 소장한 내력을 살필 수 있다. 이 그림은 특이하게 향좌 측면에 소장 내력을 적은 묵서(墨書)를 가지고 있다. 내용은 대략 ‘규산(圭山) 조영승(曺營承,

\footnotetext{
41 양수정, 앞의 글(2017), pp. 49-51.

42 박규수 著, 조효순 譯, 『居家雜服放』(석실, 2000), p. 159.

43 金昌業, 『老稼齋燕行日記』3,12月 23日(壬申).

44 황정연, 앞의 글(2008), pp. 302-303.

45 李德惁, 『靑莊館全書』38, 「否否落落書 3」, [萬壽期]; 成海應, 『研經齋全集』42, 「皇明遺民傳」6.

46 유물 열람과 이미지 사용을 허락해주신 국립중앙박물관측에 감사드린다.
} 

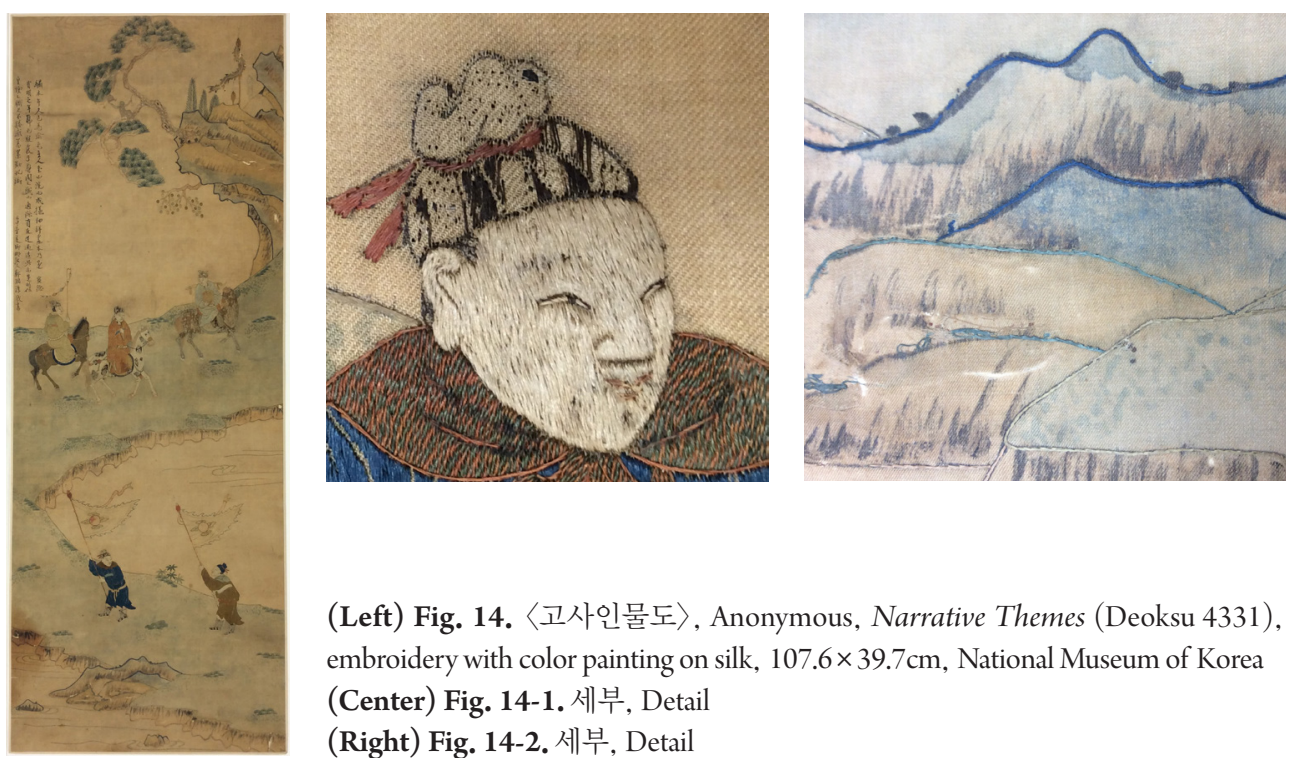

(Left) Fig. 14. 〈고사인물도〉, Anonymous, Narrative Themes (Deoksu 4331), embroidery with color painting on silk, $107.6 \times 39.7 \mathrm{~cm}$, National Museum of Korea (Center) Fig. 14-1. 세부, Detail

(Right) Fig. 14-2. 세부, Detail

1805 ?)이 소장한 것이 세월이 오래되어 이미 색이 바랬는데 때를 벗겨 모양을 갖추자 정붕순 (鄭朋淳, ? ?)에게 제발을 부탁하여 쓰게 되었다'는 것으로 '壬申季夏” 즉 1872년 여름에 감상하였다는 것을 알 수 있다. ${ }^{47}$ 제작 시기는 정확히 알 수 없으나 이 유물은 앞서〈Table 1〉의 〈고사인물도〉처럼 전형적인 之자형 구도에 회수가 조화되었으며, 각 등장인물들과 각종 기물이 사실적으로 묘사되었고 그 자수기법이 정교하다(Fig. 14-1). 그러나 이 그림의 토파나 산석을 그린 먹선(Fig. 14-2)은 앞서 본 강희연간에 제작된 〈Table 1〉의 〈위렵도축〉과 같은 고수의 〈고사인물도〉화본들과 고수작인 전인헌왕후작 〈신선도〉의 이음수로 외곽을 두른 백묘풍 묘사와는 대조적으로 상당히 거칠다. 반면, 산석 주름(Fig. 17)의 묘사는 청대작으로 알려진 고수의 일부 고사인물도와 전 정명공주작〈고사인물도〉와는 유사함이 파악된다. 또한 이 미상 〈고사인물도〉의 나무를 묘사한 회수기법은 정정명공주작〈고사인물도〉의 경우(Fig. 16)와 비슷하다. 따라서 이 그림의 제작시기는 강희연간 이후의 18 세기 작으로 추정해 볼 수 있다.

그리고 이 유물의 제발을 통해 이 유물의 소장자와 감상자의 신분과 출생지에 따른

47 제발-紼本年久, 已爲渝色, 主人圭山, 浣而成樣. 細詳畫本, 乃是宣德, 有明之年號也. 敢發于尊周之誠. 而適際 有友遇過造此, 亦是時任皇愃之職也. 不勝感舊累勸記識. 壬申季夏琅躯後人 鄭朋淳 敬書. 
고수의 존재와 조선 자수와의 상관을 고려할 수 있다. ${ }^{48}$ 감상자 정붕순은 이 그림을 명 선덕 (宣德, 1426 1435)연간의 중국 화본으로 인식하고 있어서, 고수에 대해 전혀 모르고 있었 다고 판단된다. 20 세기 초 이왕가박물관에서도 전인헌왕후작으로 구입한 고수 〈신선도〉의 내력이라던가, 숙종의 개장 사례로 보아 숙종연간 전후를 제외하고, 조선 후기에는 고수가 소장되었지만 내력을 모른 채 후손에게 전래되었다고 추정된다. 또한 지방 사가에서 소장 된 고수도 왕실처럼 사대부 남성들에게는 감상용이 되었고 여성들에게는 교본으로 활용되 었을 것으로 여겨진다. 따라서 우리나라 민수[지방수]의 특징으로 이야기되는 푼사의 사용 은 이런 고수의 작풍과 직접적으로 상관될 가능성이 크다고 상정된다.

\section{2. 조선에서 고수풍의 전개}

본 장은 고수풍의 양식을 담고 왕실소장으로 추정되는 국립중앙박물관 소장 〈전정명 공주작 자수〉(덕수 6030)(이하 〈고사인물도〉)를 통해 고수의 전개 양상과 자수사적 의미를 좀더 살피고자 한다. 〈고사인물도〉(Table 2-(1)-(ㄱ)는 진채의 청록산수계 자수그림으로, 화면 배치 상 상단에 동방삭(東方朔), 하단에 귀인(貴人)을 배치한 2단 구도의 유물이다. 등장 인물은 기품있는 귀인의 모습에 장식성 짙은 복장식을 하고 있으며, 장엄성 짙은 청록산수계 배경과 크기로 보아, 구복의 강한 기원성을 담은 의장용으로 추정된다. 이 자수그림의 가장 두드러진 특징은 등장인물의 안면은 시수되었지만, 이목구비는 보필로 묘사되었으며, 인물들을 제외하고 대부분 도상에는 회수를 사용하였다는 것이다. 특히 이음수로 바위의 외곽을 두르고 산석 등에는 청록계의 진채가 사용된 2 단의 상·하단 구도이지만, 그 흐름이 매끄럽지 못하여, 개작 가능성이 엿보인다. 이런 몇몇 특징들은 전인헌왕후작자수그림

48 정붕순 자료, 『承政院日記』, 高宗 4年 丁卯, 2月 29日.; 조영승 자료, 『沙厓先生文集」 2, 詩」, [曹圭山 禜承, 高仁峯 濟琳 約余會于宋氏山齋. 是日大雪至夜. 二首, 閔甾顯, 『沙厓集」, 해제 참조(한국고전종합 DB); 소장 자 규산 조영승은 계유년(1693)에 문과에 급제하여 사헌부 감찰을 거쳐 장연(長連) 현감을 역임한 조선휘(曺 善徽)의 5 세손으로, 문장과 시부(詩賦)가 당세에 이름났으며, 계묘(1843)에 문과에 급제하여 태천형감을 지 냈고, 사간원 장령(掌令)등의 벼슬을 역임하였다. 조영승은 사애(沙厓) 민주현(閔甾顯, 1808 1882)의 47세 (1854)때 전라남도 광주 무등산의 서석(瑞石)을 함께 유람하고〈서석록(瑞石錄)〉을 짓기도 하였다. 민주현은 매산(梅山) 홍직필(洪直硬, 1776 1852)의 문인으로 전라도 화순(和順) 지역에서 활동한 문신 겸 학자이다. 또한 감상자 정붕순은 어영청(御營廳)의 집춘영(集春營)에 입직한 초관(哨官)(1867)을 임했던 자로 연혁 추 적에 참고할 만한 자료가 많지 않았다. 그러나 정붕순의 고향이 전라도 화순이기에, 중앙에 있을 때 민주현 과의 동향 인연으로, 소장자인 조영승과 친분이 이어졌을 상황을 추정해 볼 수 있다. 본 자수그림은 입수나 유통경로에 관한 상세한 정보가 공개되지 않아, 자세한 연구는 추후를 기약코자 한다. 
〈신선도〉에서도 볼 수 있는 것으로, ${ }^{49}$ 명청대 고수와 연관된다고 할 수 있다. 따라서 1) 모수, 2) 회수 3) 자수기법의 다양성 4) 자수그림과 근대 인식으로 나누어 〈고사인물도〉의 제작 양상과 고수와의 상관을 정리해 보겠다.

1) 모수

〈고사인물도〉(Table 2-(1)-(ㄱ)는 고수 작품들의 여러 특징적인 요소들을 복합하여 제작 한 것으로 판단된다. 우선 〈고사인물도〉의 도상은 상단의 동방삭(Table 2-(1)-(ㄱ)을 제외 하고, 하단의 두 인물들(Table 2-(1)-(ㄴ))이 원대화가이자 송대 종실이었던 조창운(趙蒼雲, 13 세기 후반 14 세기 전반 활동)의 〈유신완조입천태산도(劉晨阮肇入天台山圖〉(Table 2-(2), 이하 조창운본)와 연관된다. ${ }^{50}$ 여기에 조창운본을 재현한 청대 고수 〈유완입천태도경편 (劉阮入天台圖鏡片)〉의 도상 일부(Table 2-(3))와 〈군선축수도경편(群仙祝壽圖鏡片)〉의 도상 일부(Table 2-(4))를 복합한 모수작이 〈고사인물도〉(Table 2-(1)-(ㄱ)로 판단된다. 따라서 〈고사인물도〉는 청대 고수본의 고사도(Table 2-(3) 양식과 신선도 양식(Table 2-(4))을 서로 차용, 조합한 것이라 상정할 수 있다.

이러한 현상은 명작을 모수하던 고수의 특징이 시간이 흘러 다른 여성들의 자수교본 으로 모본이 되고, 모수의 대상이 되면서 제작자나 구매자의 의도를 감안하여 재구성되면서 발생한 일로 추정된다. 한희맹을 비롯한 고수에서는 구매자의 신분과 취향을 담아 제작한 등장인물의 사실적인 의습문과 배색을 통해, 〈Table 1〉처럼 회화성 강한 〈고사인물도〉류 작 품을 다수 남기고 있었기 때문에, 이런 양식은 고수의 전형(교본)이 되었을 것으로 고려된다.

그러므로 〈고사인물도〉의 복장식 또한 이러한 양상을 가지고 있다고 판단된다. 즉 청대 고수인 〈유원입천태도경편〉(Table 2-(3))과 〈군선축수도경편〉(Table 2-(4))은 〈조창운본〉 (Table 2-(2) 인물의 도상과 복장을 바탕으로 재현한 것이며, 〈고사인물도〉(Table 2-(1)-(ㄴ)는 이를 복합한 것으로 추정된다. 즉 〈고사인물도〉의 상하단 중심인물들의 복식 의습문 (Table 2-(1)-(ㄴ), 노란 네모 틀)은 '격자문', '쌍마름모문과 4개의 연화점문', '육각문안에

49 양수정, 앞의 글(2016, (b), pp. 52-61.

50 조창운의 〈유신완조입천태산도〉는 이공린의 백묘법을 사용하여 그린 것이다. '유완천태고사(劉阮天台古事)' 는 후한 영평5년(62), 염현(저장성 승현)의 사람 유신(劉晨)과 완조(阮肇)가 天台山(浙江 天台縣北)에 약을 캐러 갔다가 두 선녀(仙女)를 만나 반년 동안 지냈는데, 고향에 돌아와 보니 벌써 7세기가 지나버렸다는 내 용이다.(한국고전종합 $\mathrm{DB}$ ) 
〈Table 2〉 전정명공주작 〈고사인물도〉와 청대 고수 〈자수그림〉의 비교, Comparison between Narrative Themes, Attributed to Princess JungMyeong (1578 1626)'s and Gu's embroidery of the Qing Period ${ }^{51}$

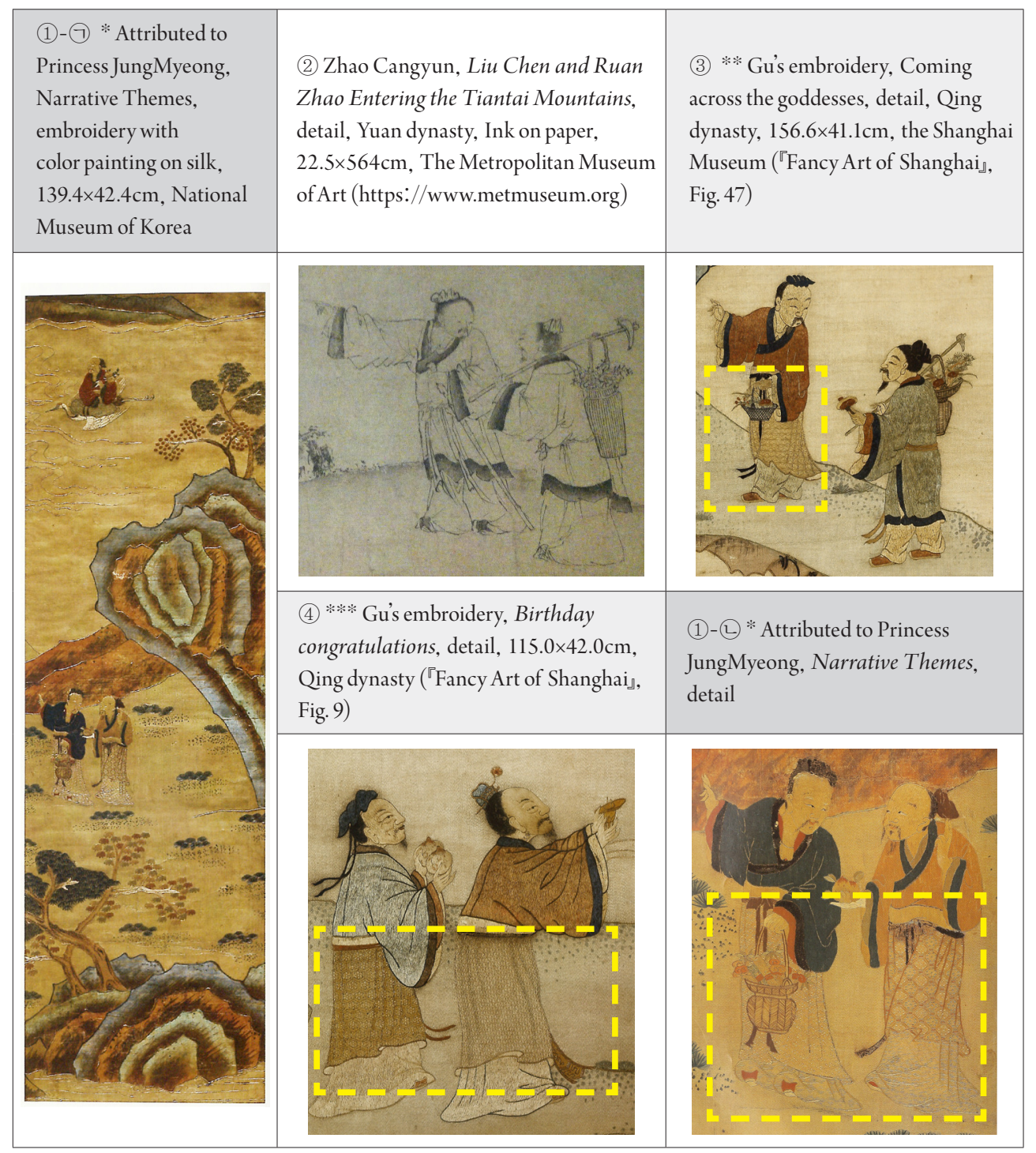

51 양수정, 앞의 글(2016, (a)), 〈표 24〉재인용. 
9점의 연화점문', '마엽문(麻葉文)', 52 '마름모안의 5 중 가로선문' 등이 구사되어 있는데, 〈Table 2-(3), (4)〉의 '노란 네모 틀' 안의 시자(侍子) 복식의 망수 및 금문수와 아주 유사하다. 이 도상을 〈Table 3〉로 정리해 보았다.

이런 상세한 의습 문양의 재현은 고수의 작품들에서 쉽게 보여지는 현상으로 역시 교본 으로서 고수의 위치가 짐작되는 부분이라고 할 수 있다. 또한 이러한 장식성 강한 의습문의 묘사는 조선 17 세기 회화나 자수에서는 잘 구사되지 않고, 조선 후기에 제작된 자수그림 '요지연도(瑤池宴圖)'를 포함한 여러 고사인물도의 인물 복장식에서 살펴지므로, 궁정이나 권문가의 취향이나 주문에 따라 제작되는 현실성과 시대성을 보여주는 것이다. 더욱이 〈고사인물도〉 중 오른편에 선 인물(Table 5-(1)-(ㄴ)이 검지와 중지를 세워 하늘을 가리키는 기호학적 도상을 하고 있는데, 이는 동양의 성인도상과 종교도상을 통틀어서 쉽게 볼 수 있는 동작은 아니어서, 제작 당시 사회적 배경을 담아 제작했을 가능성도 있다. 예컨대 이 수신호는 천주학(天主學) 사상을 암시하는 것으로, 이 도상도〈상우도(尚友圖)〉(張琦, 項聖 謨, 清, 上海博物館藏)와〈동기창반신상(董其昌牛身像)〉(顧沅, 『古聖賢像傳略』, 1830)에서 볼 수 있는 동기창의 전형을 모수한 것이라고 할 수 있다. ${ }^{53}$ 이처럼 회화에서 등장하던 기호 학적 도상이 자수그림에 사용된 만큼, 한희맹의 부군 고수잠의 스승이 동기창이었다는 점에서도, 이 자수를 주문하거나 제작한 사람이 송강파를 인식하고 있는 자이거나, 천주학에 대한 어느 정도의 지식이 전제된 사람일 가능성도 있어 편년 추정에 도움이 될 수 있다고 생각한다. 따라서 모수는 조선 후기 이후 신사임당의 초충도를 동아대학교 소장의 자수초 충도병풍〉(각 폭당 $61.0 \times 40.0 \mathrm{~cm}$ )과 숙명여자대학교 박물관 소장의 〈초충도병풍〉 $(30 \times 54 \mathrm{~cm}$ ) 처럼 4폭, 6 폭의 비슷한 도상을 담은 화조도류 병풍들로 제작한 것처럼, 여공의 교본으로서 또는 주문자의 취향에 맞춰 제작, 감상하는 사회적 유행을 따르는 방법이었다고 정리할 수 있다.

52 심연옥, 「고려불화 수월관음도의 복식직물과 문양」, 『미술사학연구』273(2012), pp. 13-14, 中江克已『文樣の 名前で讀)み解く日本史」(靑春出版社, 2004), p. 72, 재인용. 마엽문은 '눈과 얼음의 결정체 모양'으로 일본 平 安時代(800 1160)에 사용이 시작하여 江戸時代(1600 1867)에 유행하였는데 이 문양에 대한 정확한 문헌적 근거는 찾아 볼 수 없다고 한다.; 이 문양이 일본을 비롯해서 고려불화나 신선도, 혹은 옷의 문양에 직접 쓰 였던 것으로 추측되지만, 중국 청대 고수의 고사인물도에서 금문수가 주로 사용된 것으로 보아 명청대에 유 행한 복식문양이며 자수그림의 도상으로 유행한 듯하다. 숙종 어제 〈서왕모도〉에서 서왕모의 복식에서도 등 장하고 조선 19세기 자수그림병풍에도 등장하는데 이때에는 기물문양으로 살펴진다.

53 장진성, 「董其昌과 서양기하학」, 『美術史學研究』256(2007). pp. 159-182. 
〈Table 3〉 〈고사인물도〉에 사용된 금문수

Brocade embroidery on the 'Narrative Themes'

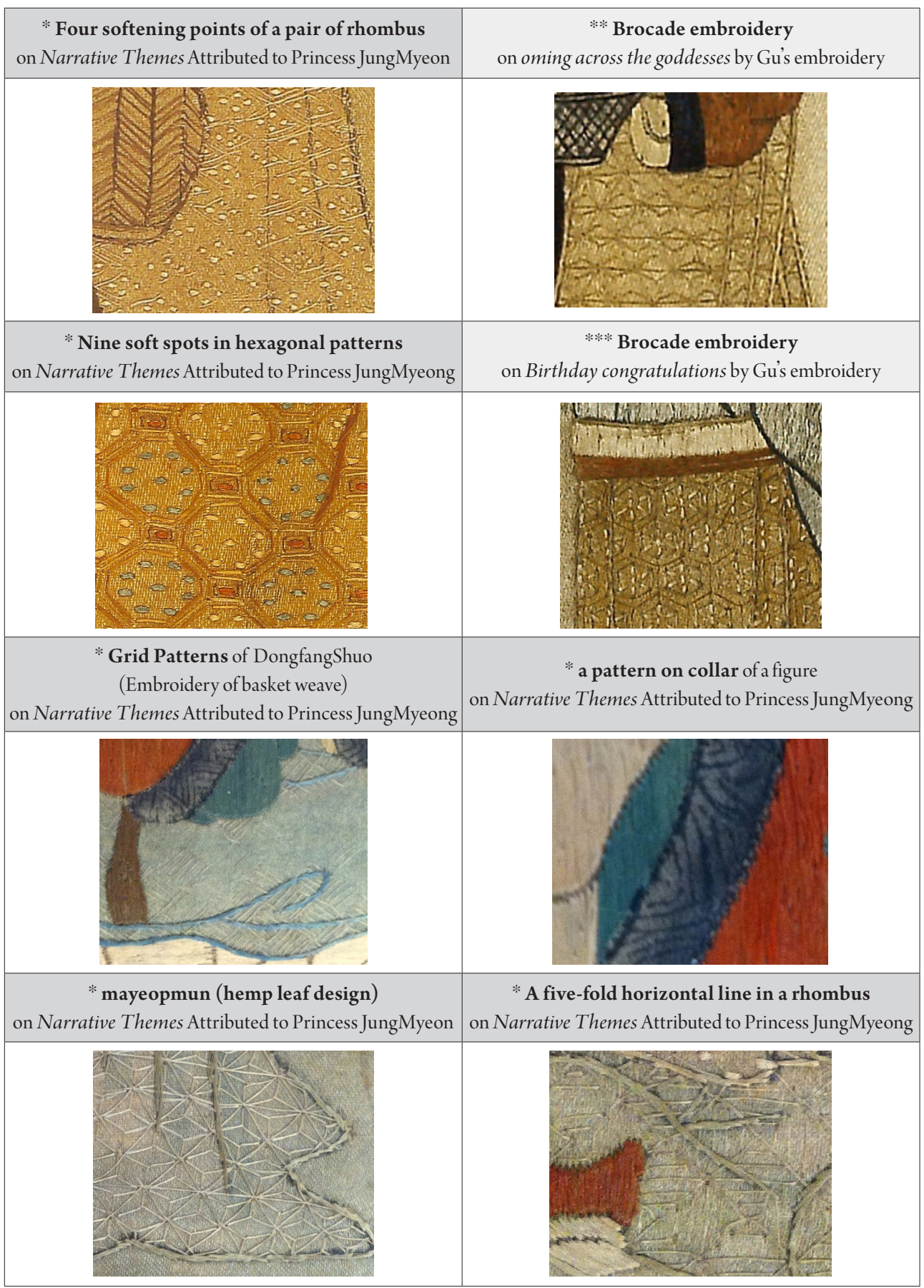




\section{2) 회수}

또한 〈고사인물도〉(Table 2-(1)-(ㄱ)는 화면구도에 있어서도 불안정한 흐름을 보이고 있어 개작의 의구심을 갖게 한다. 실제〈Table 4〉의 청대 고수〈유원입천태도경편〉(Table 4-(1))의 之형 구도와 비교하여 보면, 〈고사인물도〉(Table 4-(2)는 이 그림의 향우 측 부분에 해당 된다. 따라서 어떤 이유인지 임의로 재단, 개작된 것이라고 추정할 수 있다. 이러한 개작 가능성은 고수의 특징인 중심인물을 제외한 부분에 담채로 보채하던 회수 기법에서 발단을

\section{〈Table 4〉 전정명공주작자수의 개작 가능성}

\section{Possibility of re-production on the 'Narrative Themes painting'}

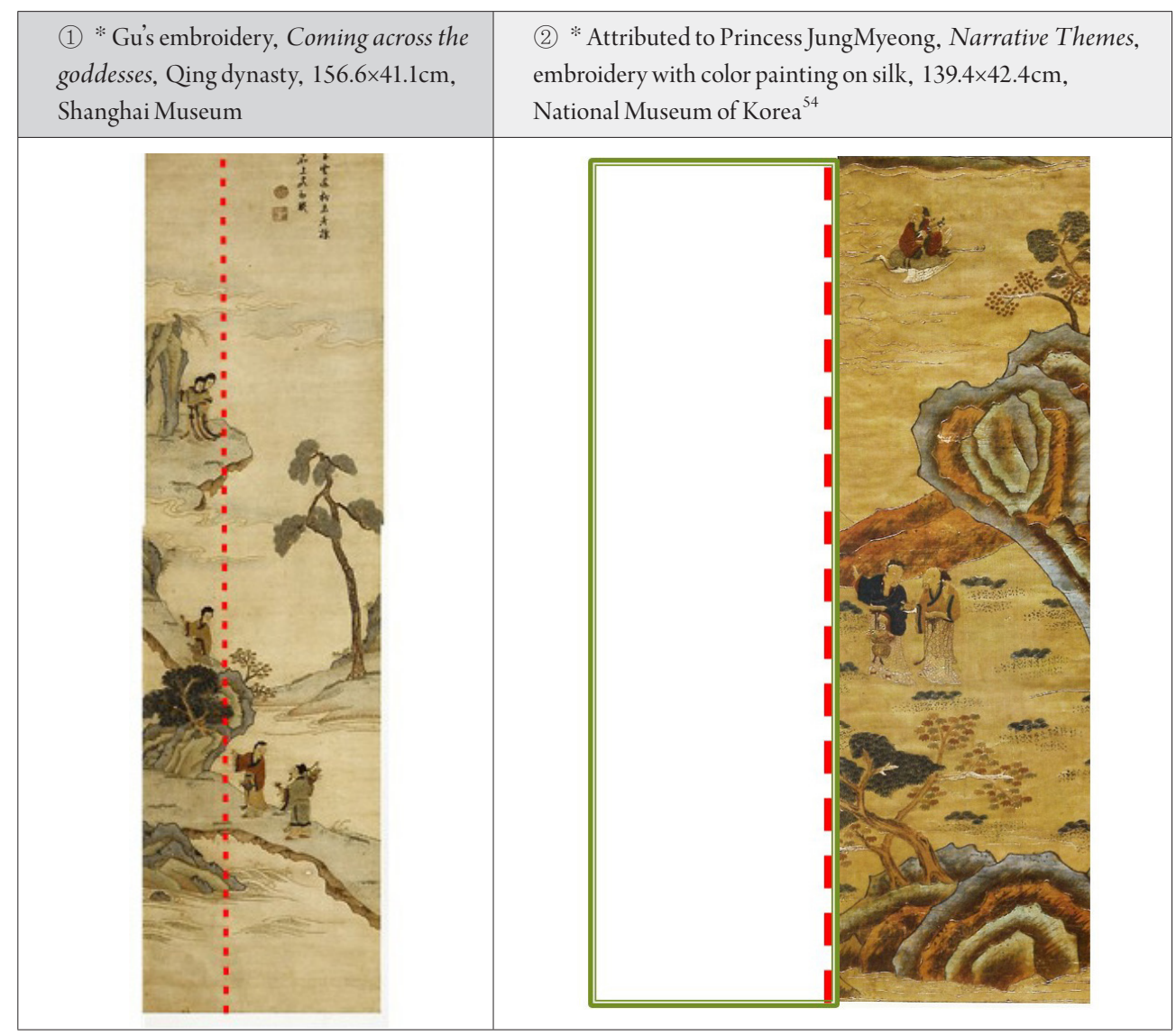

54 유물 열람과 이미지 사용을 허락해주신 국립중앙박물관측에 감사드린다. 
추정할 수 있다. 회수는 일찍이 지배자의 의상에 '윗옷은 그림을 그리고, 치마에는 수를 놓는다[上繪而下繡]'는 제작 방법이 있었고, 고려에 이어 조선 왕실에서도 낯설지 않는 기법이다. ${ }^{55}$

조선 17세기로 추정되는 출토물〈운안흥배(雲雁胸背)〉(Fig. 15)에서도 활짝 편 기러기 날개 깃털의 음영이라든가, 바위와 모란 그리고 꽃받침의 요철 묘사를 보묵과 자수를 이용 한 회수(Fig. 15-1)로 감각적으로 재현한 것을 볼 수 있다.

그러므로 문예사적으로 회수는 완성본의 질을 높이거나, 제작 상 미흡한 실력을 대체할 수 있는 등 다양한 목적으로 사용되었을 것이다. 그러나 분절을 통해 개장을 가능케 하는 방법이기도 하였다. 이미 현재 전하는 회화에서도 일부 분절 사례는 긍정적 의미도 담고 있으나, 더러는 원형을 훼손하거나, 불분명한 의도의 경우도 쉽게 찾을 수 있다. 더욱이 숙종도 어람 후 자수를 다시 첨하여 가리개로 개장을 명한 바 있고, 정명공주의 후손인 홍경모도 옛부터 집안에 소장 중이던 자수그림 〈춘유방초도〉를 조상 유품이지만, 이를 임의로 표구하여 축으로 개장, 보관하고 있었다는 기록도 전한다. ${ }^{57}$ 이런 경우에는 시대적
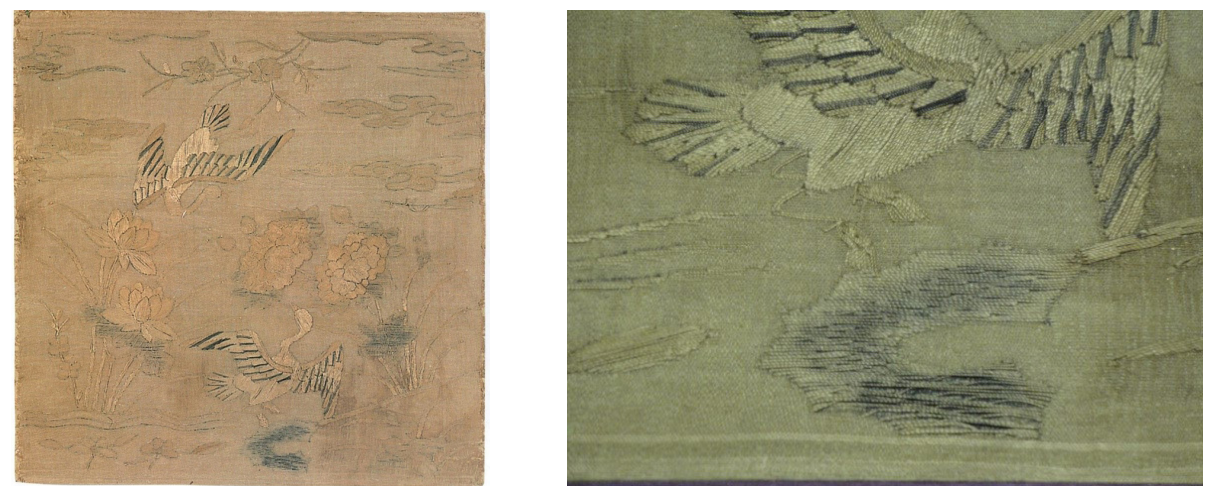

(Left) Fig. 15. 〈雲雁胸背〉, Badge, $36 \times 36 \mathrm{~cm}$, SeokJuseon Memorial Museum at Dankook University ${ }^{56}$ (Right) Fig. 15-1. 세부, Detail

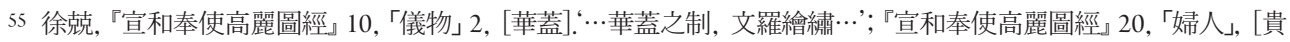

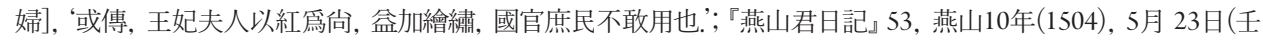
子), 藍羅童子葡萄雙膝闌、蓮邊具泥金盡成裙次九幅入內.; 承政院日記』27, 仁祖 7 年(1629), 7月 24日. 洪命耆 以向衣院官員以提調意啓日, 觀武才擧動時, 大殿·世子宮進御胸背畫造泥金, 當入一兩牛, 而上年赴京之行, 貿 易之金, 戸曹以爲本曹多有所儲, 不爲貿易, 而至今不䢪。本院打造泥金之役, 非數三日所可爲, 令户曹極擇泥 金, 及時輸送, 俾無生事之患, 何如? 傳日, 依啓.; ‘承政院日記』27, 仁祖 7年(1629), 7月 25日.

56 유물 열람과 이미지 사용을 허락해주신 단국대학교 석주선박물관측에 감사드린다.

57 홍경모 지음, 이종묵 옮김, 『사의당지, 우리집을 말한다„(휴머니스트, 2009), pp. 204-210, p. 233, p. 325 
양상이나 유행하는 기법과 도상이 첨삭될 가능성도 크다. 따라서 회수는 자수한 부분을 제외한 도상 일부분에 보채, 또는 자수를 첨하거나, 혹은 자수된 면 위에 보필을 첨할 수도 있으며, 때로는 문인 감상의 기호를 충족시키는 보필이 가해질 수 있다. 또한 이런 보필된 부분은 적절한 도상의 흐름에 맞춰 필요에 따라 재단을 가능케 하며, 이후 가리개나 족자, 병풍 등으로 개작, 표구할 수 있는 대상이었다고 판단되며, 이러한 양상은 중국 청말 이후에 가장 성행하기도 하였다. 즉 보묵, 보채는 명말 초창기 고수본에 있어 사실성과 회화성을 높이는 긍정적인 기법이었지만, 청대로 갈수록 자수보다는 채색으로 묘사되는 경우가 많아 고수의 특징을 잃어버리고 개작 또는 개장의 요인이 되었다고 여겨진다.

〈고사인물도〉에서 회수는 시수 후 붓을 과감하고 자유롭게 다룰 수 있는 전문가의 손을 거친 듯한 나무 줄기(Fig. 16)와 암석(Fig. 17)의 세부 묘사 그리고 등장인물의 눈썹과 수염 (Table 5-(1)-(ㄱ), (ㄴ)), 배경의 일부에 사용되었다. 특히 청록 진채로 인해 장식성이 더욱 강조 되었다고 볼 수 있는데, 기존 고수에서 보이는 청록담채의 양식과는 다르다. 그리고 등장 인물의 머리 부분이 박락된 자수 흔적으로 보아, 〈고사인물도〉의 진채는 근대 어느 시점에 청록만 다시 보채된 후, 매매되었을 가능성도 있다. 결국 이러한 특징은 시대와 풍속, 미술사 적 고찰 및 진위 판단에 도움을 준다고 사료된다.

또한 청대 고수작인 전인헌왕후작자수 〈신선도〉에도 눈썹과 수염과 일부 나무와 배경 에는 보필과 보채가 있는 반면, 전인헌왕후작자수〈춘유방초도〉에서는 이목구비가 시수 되어 있어, 고수의 영향보다는 조선에 있었던 다른 화풍의 존재도 있었다고 짐작해볼 수
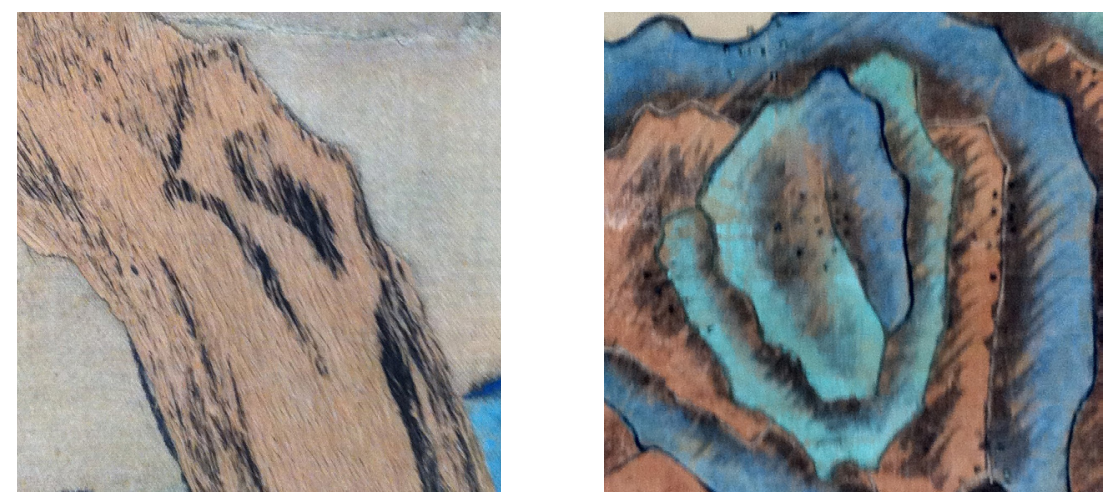

(Left) Fig. 16. 나무, 전정명공주작 세부, Tree, detail, Narrative Themes, Attributed to Princess JungMyeong

(Right) Fig. 17. 암석, 전정명공주작 세부, Rock, detail, Narrative Themes, Attributed to Princess JungMyeong 
〈Table 5〉이목구비의 묘사, Description of facial features

(1)

있다. ${ }^{58}$ 즉 조선 19세기 작 〈경직도〉(Table 5-(2)-(ㄱ)와 〈고사인물도〉(Table 5-(2)-(ㄴ)처럼 이목 구비와 나무줄기 껍질까지도 시수하는 조선적인 작풍의 정형화된 양식이 있었다는 것이 추정된다. 따라서 이러한 회수는 정명공주 생전 시기의 기준작이 별도로 없어서 단언할 수 없지만. 후대 개작이 시도될 때 분절을 용이하게 하는 제작 방법이 되었다고 판단된다.

58 양수정, 「조선 궁중의 수화에 대한 시론-전인헌왕후작 자수의 〈춘유방초도〉를 중심으로」, 『(동아시아의) 궁 중미술 : 김홍남 교수 정년퇴임 기념 논문집』(서울: 한국미술연구소, 2013), pp. 388-398.; 이 문제는 보다 심 도있는 내용이어서 추후 다른 논문을 통해 발표하고자 한다. 


\section{3) 자수기법의 다양성}

〈고사인물도〉는 화려한 색상의 수실과 금사(金絲)를 사용하지 않았지만, 단순한 면을 채우는 자련수와 평수 이외 이음수를 이용한 선수(線繡)의 금문수가 등장하면서, 다양한 자수기법을 바탕으로 회화적 사실성과 고급 취향을 갖추고 있다. 원명대(元明代)에는 종교 적인 의미가 강한 불교변상, 신장상과 보살도와 같은 자수그림이 제작되면서, 주로 백묘화 (白描畫)와 같은 단채사의 구륵 선묘를 사용하여 종교적인 의도와 부합되게 제작되는 작풍도 있었다. 이때 기법 상 이음수의 발전이 선도된 것으로 판단된다. 특히 명말 고수가 유행 되면서 절파풍의 역동적인 필선은 사선평수나 짧은 사선평수로 재현되었지만, 불교자수가 제작되면서 차차 이음수가 유행되었고, 이에 따라 고수도 정제된 기법으로 이음수를 윤곽선에 사용하게 되었다고 여겨진다. 즉 조선 17 세기 흉배를 비롯한 의장용, 불교공덕용 자수 그림도 마찬가지로, 통상 윤곽선은 짧은 사선평수나 접침(接針)으로 구사되다가, 차차 이음 수로 기법상의 변화를 보이고 있기 때문이다.

또한 〈고사인물도〉는 조선의 자수사적 특징으로 보는 꼰사보다는 중국의 한 양식으로 볼 수 있는 푼사가 사용되었는데, 여기에서는 운간을 위해 푼사를 사용한 한희맹의 경우와 달리, 청대 고수의 것처럼 단순히 면을 채우는데 사용되었을 뿐이다. 푼사의 경우, 우리나 라 자수사에서는 중국이나 우리나라 민수에서의 특징으로 보고 있는데, 이는 좀 더 재고의 여지가 있는 부분이다. 그것은 현재 전해오는 삼국 및 고려, 조선시대의 유물뿐만 아니라 중국 각 시대에도 꼰사나 푼사로 자수된 다양한 유물이 전해지고 있고, 두 개의 색사를 꼰 합사의 경우도 14 세기 수불을 비롯하여 고수, 전신사임당작 〈자수초충도병〉(각 폭당 $61.0 \times 40.0 \mathrm{~cm}$, 동아대 소장), 전인헌왕후작 〈신선도〉, 19 세기 활옷에 이르기까지 장식성과 견고성을 높이는 데 양국에서 모두 사용된 만큼, $\mathrm{S}$ 형이나 Z형으로 제작한 꼰사나 푼사의 사용 으로 국적을 나누는 데는 연구사적으로 무리가 있다고 판단된다. 따라서 푼사가 언제 다수 사용되었는지에 중점을 둬야 한다고 사료되는데, 대체로 꼰사로 제작되는 복장수보다, 고수 처럼 회화적 운간을 용이하게 표현할 수 있는 중요한 방법 중 하나가 푼사의 사용이었 으므로, 감상용 자수그림에 적극 사용되면서 청대가 되면 더욱 푼사가 저변화되었다고 정리할 수 있다. 더욱이 산동의 노수가 꼰사로 자수하는 것이 특징인 만큼 이 문제는 좀 더 재고의 여지가 있다.

게다가 효율적인 문제에서도 실을 꼬아서 사용하는 것은 시간과 노동이 더 필요하다는 것이다. 따라서 왕실에서는 합사장(合絲匠)을 두어 실을 합한 질긴 실을 가공하여 사용하였 
는데, 꼰사 자체가 그만큼 고급적 취향을 나타내는 것이어서, 이를 충당치 못한 민가에서는 푼사를 더 선호하였다고 볼 수 있다. 그리고 〈고사인물도〉의 인물묘사에서는 윤곽선을 이음수로 정돈하지 않았는데, 이는 청대 고수작인 전인헌왕후작자수〈신선도〉에서 윤곽선 이 없는 경우와 유사하여 주목된다.

그러므로 〈고사인물도〉의 대체적인 양상은 청대 고수의 작풍을 따르고 있으나, 기존의 2-3줄의 채사로 산석의 윤곽선을 묘사하는 고수풍과 달리, 진청색의 이음수로 산줄기와 구름과 수파의 윤곽선을 구사하는 것은 1730 년도 『삼강행실도(三綱行實圖)」에서 곡선 띠를 겹겹이 겹쳐 묘사한 산과 구름, 물의 표현과 연관된다. 또한 조선 후말기 모든 사물의 윤곽선을 이음수로 시수하는 작풍에 비해 과도기적인 모습을 보이고 있어 고수의 작풍과 별도로, 시대적 양상도 담고 있는 것으로 생각된다.

따라서 조선 후기가 되면 유독 화려한 채색의 〈요지연도(瑤池宴圖)〉를 비롯한 '고사 인물도 자수병풍'들이 다수 제작되는데, 고수에서 모수되던 많은 고사인물도 도상의 재현 방식과 스토리 전개 및 자수기법 등이 조선 후기 자수그림의 제작과 유행에 다소의 상관이 있다고 볼 수 있으며, 다음과 같이 제반사항을 정리할 수 있다. 첫째, 조선 후기 왕실에서는 숙종의 명처럼 고수의 회수에 해당하는 부분을 자리수나 자련수 기법으로 메운 점, 둘째, 주문 제작이 활발해짐으로써 공교한 표현에만 치중하는 기법들이 살아남게 되는데 고수의 고사인물도처럼 장식수가 발달했다는 점, 셋째, 고수가 운간을 위해 사용한 푼사를 꼰사로 대체한 점과 이로 인해 지방수의 푼사 사용을 다소나마 예측할 수 있다는 점, 넷째, 고수와 달리 모든 도상의 외곽선을 이음수로 둘러 정연함을 강조한 점, 다섯째, 간색보다는 보색의 대비를 이용한 점, 여섯째, '자수고사인물도와 자수신선도'가 등장한 점, 일곱째, 당시 자수 그림은 회화 도상을 취하면서 문예적 기득권을 고수함과 아울러, 기법의 다양성에 의해 공교한 표현이 강조되었고, 또한 금사 등의 고급재료를 사용하는 등 보다 고급화된 치장을 선호하는 방향으로 나아간 점 등은 고수의 내력과 상관된다고 할 수 있으며, 조선 자수의 발전과 성숙 단계와도 관련된다고 상정된다. 그러므로 이 일련의 상관들은 조선말기가 되면 중국보다 명성이 높았던 조선 자수의 정형적인 작풍으로 발전된다고 정리할 수 있다.

4) 자수그림과 근대 인식

지금까지 〈고사인물도〉를 통해 명청대 고수의 작풍 양상과 조선 후기에 유입된 고수와 관련된 유물들을 통해 조선 후기 자수와 상관되는 내력을 살펴보았다. 본 글을 마무리하면서 
근대기에 입수된 이 유물이 가지는 당시 자수에 대한 인식과 위치를 잠시 재고해보고자 한 다. 이 유물은 1916년 이왕가박물관에서 이성혁(李性赫)으로부터 구입한 것으로, 상세한 내 력이 없이 왕실가 여성인 정명공주의 전칭작으로 입수된 것이다. 이왕가박물관은 유물 수집 기간인 10년 동안 이 〈고사인물도〉를 구입하던 1916 1917년까지, 개관 전부터 신문 광고 라는 구입 경로를 통해 소장유물을 적극적으로 구입하였기 때문에, 중국과 본국의 다양한 화목을 소장하게 되었고, $92.8 \%$ 라는 상당한 소장 규모를 단기간 내에 갖추게 되었다고 한다. 매도자 이성혁에 관한 상세한 자료는 없지만, 그는 1910년대 초기부터 이왕가박물관과 거래하였고, 1910년대 후반부터는 조선총독부박물관에도 유물을 제공한 개인 전문서화 컬렉터였다고 연구되기도 하였다. ${ }^{59}$ 또한 1920 년대 말까지는 왕실과 관련된 김홍도, 신윤복과 같은 화원들의 작품과 책가도와 일월오봉병풍과 같은 장식화 그리고 의궤나 기록화 등 진위가 분명하고 수준 높은 작품을 취급하였다고 한다. ${ }^{60}$ 이처럼 수십 년간 매매에 적극적이 었던 그가 1930년 이후에는 자취를 드러내지 않는데, 당시 친일귀족을 포함하여, 중요한 근대 수장가로서 언급되는 박영철(朴榮吉, 1879 1939). 김용진(金容鎭), 1882 1968) 등과 같이 사회적 명성을 갖춘 고관 및 대부호들이 애호가, 호사가의 취향으로 수장하는 내력'1 과는 상당히 다른 성격의 행적이라고 할 수 있다.

이처럼 이성혁에 관한 개인적인 생애를 알 수 없는 상황에서 〈고사인물도〉를 전정명 공주작으로 매매한 의도는 자세히 알 수 없다. 또한 전인헌왕후작자수로 칭해지는 감상용 자수그림들의 국적을 비롯하여, 이 〈고사인물도〉도 분절된 일부인데, 왜 이런 작품을 거래 했는지 등 진위가 의심된다고 할 수 있다. 즉 그가 매매한 왕실여성의 자수그림 3점 모두가 그 내력이 잘못 전해진 것이어서, 왕실여성의 생전시대에 따른 작품에 대한 연구사적 재고가 두루 요구된다고 할 수 있다. 게다가 이성혁이 거래한 김홍도와 신윤복과 같은 화원작이나 의궤나 기록화는 왕실본으로서 사사로이 소통되지 못하는 것임에도 불구하고, 〈고사인물도〉와 같은 생소한 작풍의 자수그림들을 왕실 여성본으로 거래할 정도라면, 감식안이 높다기보다는 여하의 왕실가 유물을 매매하는 전문경매인일 가능성도 배제할 수 없다. 그것은 당시 왕실 소장품에 대한 가치가 수장가들에게는 큰 관심거리였지만, 왕실본의 소장 루트는 은밀하게

\footnotetext{
59 박계리, 「20세기 한국회화에서의 전통론」(이화여자대학교 박사학위논문, 2006), pp. 104-195.

60 박계리, 위의 글(2006), pp. 104-195. 이성혁의 수장물에 대한 내용 참조.

61 김상엽, 「『故朴榮喆氏寄贈書畫類展觀目錄』을 통해 본 다산(多山) 박영철(朴榮吉, 1879 1939)의 수장활동」, 『문화재』44-4(2011), pp. 71-80.
} 
또는 신개념인 경매를 통해 매매하는 경우도 있었기 때문이다. 예를 들어 영친왕(英親王, 1897 1970)이 도일(渡日)(1907) 후 혼수로 준비한 물건이 소용없게 되자, 창덕궁 뜰에 내놓고 경매를 불러 상인배에게 팔았던 일도 있었던 사례도 있었다. ${ }^{62}$ 그리고 $18 \sim 19$ 세기에는 청 황실을 비롯하여 조선인 염상(鹽商) 안기(安岐, $1683 \sim 1745$ 이후)와 같은 청대 거상(巨商)들도 송·명대 자수그림과 격사그림과 아울러 고수와 같은 명성 높은 자수그림들이 소장되어 '희신상기(喜新向奇)'의 취향으로 감상 대상이 되었다. 그러나 청말에 이르면 수준 높은 고수는 제작되지 않았고, 그 진품은 대부분 황실과 고관, 거상의 소유여서 일반인들이 쉽게 접할 수 없었다.

20세기 초가 되면 중국에서는 고수의 이름을 걸고 여홍전습소(女紅傳習所, 1914)가 운영되고 있었는데, 소장 겸 교습을 담당했던 심수(沈壽, 1874 1921, 號, 雪宦)가 고수의 작풍에 근대 서양회화와 사진예술을 접목한 새로운 묘법으로 명성을 높이고 있었다. ${ }^{63}$ 따라서 근대에 이르면 전성기에 제작된 고수는 고미술품의 의미로 명성이 유지되고 있었는데, 앞 서 언급한 개작된 고수작들이 상세한 내막을 모른 채, 조선 이왕가박물관에 왕실가 여성의 작품으로 입수된 사회 분위기와 연결된다고 할 수 있다. 가령 이들을 구입하기 바로 전 해인 1915년에는 조선총독부 주최로 조선물산공진회(朝鮮物産共進會)(1915)가 개최되었는데, 그 때 명 황제 신종(神宗, 1563 1620)과 관련이 있는 『전가진완(傳家珍玩)』(1605)이 조선 자수의 대표작으로 전시된 적 있었다. 이 전시 이후 근대 조선 사회에서 자수의 위치는 옛 자수품도 가치 있는 고미술품의 대상으로 부상했음은 물론이다. 그리고 이즈음 일본으로 자수나 미술 공부를 위해 유학하는 여학생들이 증가했으며, 초중등여성교육과정에 자수가 기초 교육으로 본격화되는 것도 이 시기였다. 따라서 당시 이왕가박물관에서 왕실 (여성)자수품의 수집은 시급한 문제였을 것으로 추정해 볼 수 있다.

더욱이 이런 내력 중 1930년경 무렵부터 고수에 대한 관심이 다시 생기게 되는데, 그것은 청말민초(清末民初)의 정치가인 주계검(朱啓鈴, 1871 1964)이 쓴 『여홍전정략(女紅傳征略)』, 『사수필기(絲縹記)』, 『청내부장격사서화고(淸內府藏刻絲書畫考)』와『청내부자수서화고 (清內府刺繡書畫考)』(合肥闞鐸霍初校, 1930)와 같은 저서들이 세상에 나오면서부터일 것이다. 『청내부자수서화고』는 청말 황궁에 보관중인 자수와 격사, 서화에 대한 전반적인 내력과 청대까지 전해지는 자수에 관한 대략적인 정보를 담고 있는 것이었다. 여기에 1935년 만주

62 김용숙, 『조선조 궁중풍속연구」(일지사, 1987), p. 324.

63 양수정, 앞의 글(2016 @), p. 169.; 沈壽口述, 張謇整理, 王逸君譯註, 앞의 책(2004). 
국립박물관(滿洲國立博物館)과 동경의 좌우보간행회(座右寶刊行會)에서 함께 출간한『찬조 영화』가 고수의 골동품 유행에 정점을 찍은 것으로 보인다. 이 도록에는 주계검이 자신이 들

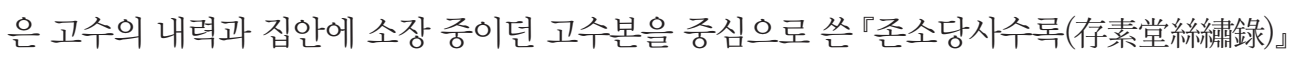
을 싣게 되는데 이 글이 영문, 일문, 중문으로 소개되면서, 고수가 공식적으로 서양을 비롯 한 여러 학계에까지 주목받게 되는 계기가 되었다. 또한 앞서 언급한 서울남의『고수고』 (1937)도 이어 편찬됨에 따라, 고수에 관한 관심은 1930년경부터 급격히 고조되었다는 것을 알 수 있었다.

이처럼 〈고사인물도〉는 청대 고수의 특징과 조선 후기 이후 전개되는 근대 사회 배경 속에 전개되는 자수의 시대성도 담고 있었다. 이러한 유물의 등장은 조선후기 자수사의 전 개에 있어 나름 궁금했던 문제들에 대해 추론을 시도해 볼 수 있는 좋은 자료였다고 생각 된다. 그리고 다양한 수준의 고수가 어떠한 경로로 입수되었든 시대가 지남에 따라 소장층이 달라지면서, 중앙에서, 지방으로 또는 집안의 자수로 다양한 상관을 보여주고 있어서, 이를 바탕으로 부재한 조선 자수사 연구에 다양한 담론이 제기되길 고대한다.

\section{IV. 맺음말}

조선시대에는 17 세기를 기해 왕실과 권문층을 중심으로 고수작을 포함한 중국의 이름 난 지방수의 작품들이 유입되어 감상되기도 하였지만, 고수풍의 감상용 자수그림의 제작은 조선 왕실 소용 이외 활발하지 않았다고 판단된다. 이러한 현상은 우선 수장의 대상으로 많은 중국 서화가 유입되고 있었지만, 완물상지의 관점 때문에 감상용 자수그림은 적극적인 수집대상이 되지 못하였고 이러한 풍조는 18 세기 전반까지 이어졌기 때문이다. 그리고 18 세기 중반에서야 일반 사가의 소장품에도 등장하는 감상용 자수그림은 여전히 독특하고 특별한 대상이었다. 조선 후기에는 요지연도나 곽분양도(郭汾陽圖)처럼 한아(閒雅)와 숭사 (崇奢)의 소재로 18 세기 중엽 이후 자수병풍으로도 다수 제작되면서, 저변화를 이끌게 되는 데 이런 작풍의 견인에는 자수그림 이외 회화로도 명청대 고수의 제재였던 고사인물도와 신선도가 다수 유행한 풍조와도 상관된다고 볼 수 있다. 그러나 중국과는 달리, 고수를 그대로 모수하거나 회수하는 기법의 작풍은 구사되지 않았다는 것이 조선 자수의 특징이라 고 할 수 있다. 다만 중국의 규각수가 고수에 의해서 청대에 다시 유행했던 것처럼, 이러한 풍습은 조선 후기 여성의 여공을 일변시키고 규문수(閨門繡)가 교육되고, 주문에 의해서 
제작하는 전문제작가가 등장하는 풍습으로 이어졌다고 볼 수 있다.

19 세기 초에 이르면 '중국 자수보다는 조선의 자수가 더 명성이 있다(『閏閤叢書』)'고 한 만큼 자수는 발전된 양상을 보이며, 아울러 일상용품의 장식으로 소용이 확대된 현상과도 연관된다. 즉 자리수로 면을 채우고, 금문수와 같은 장식수가 사용되거나, 외곽선에 이음수 를 사용하는 등 일부 자수기법의 용례가 선도되었으며, 이러한 작풍은 조선적인 특징으로 자리잡게 되었다. 다만 푼사를 이용해서 회화와 같이 사실적으로 재현하는 근사색(近似色) 운간법은 의장적 표현과 보색 운간법을 주로 사용하던 궁수[한양수]처럼 청완(淸玩)의 작풍에 영향을 주기보다는, 안주수처럼 감상용 자수그림을 제작해주는 전문 집단이나 지방수[민수] 또는 근대 자수에 미치는 영향이 다소 있었다고 볼 수 있다. 즉 조선의 자수 그림은 17 세기에 회화와 동일하게 보는 완물의 관점에서, 조선 후기가 되면 완물이 될 수 있는 기법의 활용을 줄이면서 '품격의 높낮음은 그 적에 있지 않고 뜻에 있다’라는 청완이 라는 문인 취향의 대세를 따라 발전하면서 조선 자수의 특징으로 자리잡은 것으로 상정된다.

* 주제어(key words)_고수(Gu's embroidery), 자수(Embroidery), 자수그림(Painted-Embroidery), 고사인물도(Narrative Themes), 궁양(Palace Style), 정명공주(Princess Jeongmyeong), 숙종(King Sukjong), 회화(Painting), 명청대(MingQing Dynasty) 


\section{참고문헌}

\section{1. 사료}

金壽恒, 『文谷集』5, 한국고전번역원 DB.

金堉,『潛谷遺稿』14, 한국고전번역원 DB.

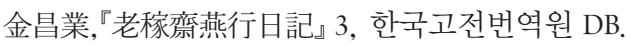

『承政院日記』 27,33 , 한국고전번역원 DB.

서울대학교규장각, 『列聖御覽』2, 3, 영인본, 2002.

成海應、『研經齋全集』42, 한국고전번역원 DB.

尹行恁, 『碩齋稿』1, 한국고전번역원 DB.

李德惁,『靑莊館全書』38, 한국고전번역원 DB.

李元翼, 『梧里先生文集』1, 한국고전번역원 DB.

李瀷, 『星湖全集』56, 한국고전번역원 DB.

李埈, 『蒼石先生文集』3, 14, 한국고전번역원 DB.

\section{2. 한국어 문헌}

김경미 외, ${ }^{『} 17$ 세기 여성 생활사자료집』 4 , 보고사, 2010.

김남기, 『『列聖御製』에 실린 조선 국왕의 題畫詩 연구」, 『한국문학논총』 $34,2003$.

「肅宗의 문예적 관심과 한시 세계」『진단학보』98, 2004.

김상엽, 『故朴榮喆氏寄贈書畫類展觀目錄』을 통해 본 다산(多山) 박영철(朴榮喆, 1879 1939)의 수 장활동」, 『문화재』44-4, 2011.

박계리, 「20세기 한국회화에서의 전통론」, 이화여자대학교 박사학위논문, 2006.

朴珪壽 著, 조효순 譯『『居家雜服放』, 석실, 2000.

서경희 역주, ${ }^{\circledR} 18$ 세기 여성생활사 자료집』6, 보고사, 2010.

심연옥, 「고려불화 수월관음도의 복식직물과 문양」,『미술사학연구』273, 2012.

「「동아대학교 박물관 소장 〈초충도수병〉의 직물과 자수 연구」, 『문화재』46-3, 2013.

안대회, 「조선 후기 취미생활과 문화현상」『한국문화』60, 2012.

양수정, 「조선시대 자수그림 연구」, 이화여자대학교 박사학위논문, 2016 (a).

,「傳 仁獻王后의 자수그림〈신선도〉연구」, 『동악미술사학』20, 2016 (b).

「조선 17세기 자수그림의 전승과 이행」, 『미술사학보』 $48,2017$.

「조선 17세기 자수그림의 移行에 관한 試論 - 節日胸背를 중심으로」, 『동악미술사학』 23 , 
2018.

, 「조선 17세기 䌗帖의 문예사적 가치」『한국민화』13, 2020.

「18세기 이후 자수(刺繡)와 제작가(製作家)에 관한 제(諸)면모」『미술사학보』54, 2020.

王亞蓉, 「명대 최고의 자수예술」, 동아시아 자수예술의 역사』. 국립고궁박물관, 2013.

이경하 역주, ${ }^{\circledR} 18$ 세기 여성생활사 자료집』2, 보고사, 2010.

이은하, 「화조문자수스란치마와 조선중기 화조화」『이승에서의 마지막 치장』, 경기도박물관, 2011.

장진성, 「董其昌과 서양기하학」『美術史學研究』256, 2007.

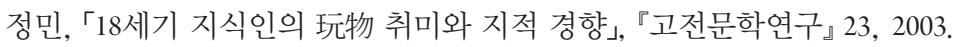

정은임, 『인목왕후와 인현왕후 - 문학의 창으로 본 조선의 궁중문화 3 „채륜출판사, 2012.

정재륜著, 강주진 譯, 『東本尉公私聞見錄』, 양영각, 1985.

정혜란, 「중국흉배와 한국흥배의 비교고찰」, 고문화』57, 2001.

조규희, 「만들어진 명작-신사임당과 초충도(草蟲圖)」, ${ }^{『}$ 미술사와 시각문화』 $12,2013$.

조인수, 「중국 원명대의 사회변동과 도교 신선도」, 『美術史學』23, 2009.

조재현 역, 『계축일기 : 인목대비 서궁에 갇히다』, 서해문집, 2003.

조효숙, 「꽃과 새가 가득한 수치마-화조문수상」, 『이승에서의 마지막 치장』, 2011.

진준현, 「그림을 좋아한 숙종 임금」, ${ }^{\circledR}$ 선비문화』9, 2006.

,「숙종의 서화취미」, 『서울대학교 박물관 연보』7, 서울대학교박물관, 1995.

홍경모 저, 이종묵 옮김, 『사의당지, 우리 집을 말한다: 18 세기 사대부가의 주거 문화』, 휴머니스트, 2009.

황정연, 「18세기 경화사족의 서화수장과 예술취향-유만주와『흠영』, 『내일을 여는 역사』 40, 2010.

\section{3. 동양어 문헌}

『顧氏畫譜』, 1603

上海博物館 工藝研究部, 『海上錦紼』, 上海博物館, 2007.

單國强, 「導言-筆墨趣味與織繡藝術」『織繡書畫』, 上海世紀出版股份社有限公司, 2005.

滿洲國立博物館, 『纂組英華』, 東京座右寶刊行會發行, 1935.

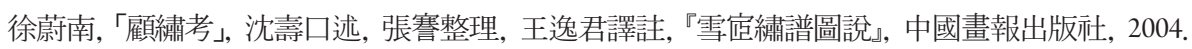

國立古宮博物院,『十指春風』, 國立古宮博物院, 2015.

趙豊, 『中國絲綢通史』, 蘇州大學校出版社, 2005.高橋義 


\section{References}

\section{Primary Sources}

Kim, Changeop(1658 1721). Nogajai Yeon Haengilgi [Nogajai's Yanxing Diary] 3, Choson 1712, Hangukgojeonbeonyeokwon DB.

Kim, Suhang(1629 1689). Mungokjib [The Collected Works of Kim Suhang] 5, Choson 1699, Hangukgojeonbeonyeokwon $\mathrm{DB}$.

Kim, Yuk(1580 1658). Jamgoyugo [Jamgok's posthumous collection] 14, Choson 1683, Hangukgojeonbeonyeokwon $\mathrm{DB}$.

Lee, Deok-mu(1741 1793). ChungjangkwanJeonseo [The Collected Works of Lee Deok-mu] 38, Choson 1900, Hangukgojeonbeonyeokwon DB.

Lee, Ik(1681 1763). Sŏngho-jŏnjib [The Collected Works of Lee Ik] 56, Hangukgojeonbeonyeokwon DB.

Lee, Jun(1560 1635). Ch'angsǒksŏnsaengmunjib [The Collected Works of Lee, Jun] 3, 14, Hangukgojeonbeonyeokwon DB.

Lee, Wonik(1547 1634). Orisŏnsaengmunjib [The Collected Works of Lee, Wonik] 1, Hangukgojeonbeonyeokwon $\mathrm{DB}$.

Seungjeongwon Diary [The Daily Records of Royal Secretariat of Joseon Dynasty]27, 33, Hangukgojeonbeonyeokwon DB.

Sŏultaehakkyo. kyujanggak (Kyujanggak Institute of Seoul National University), Yǒlsŏngǒram [Kings' Manuscript] 2,3, Yõnginbon [Facsimile edition], 2002.

Sung, Haeeung(1760 1839). Yeongyeongjaejeonjib [The Collected Works of Sung Haeeung] 42, Hangukgojeonbeonyeokwon $\mathrm{DB}$.

Yun, Haengim(1762 1801). Seokjaego [The Collected Works of Yun Haengim] 1, Choson 1870, Hangukgojeonbeonyeokwon DB.

\section{Secondary Sources in Korean}

An, Taehoe (Ahn, Daehoe). “Chosŏn hugi ch'wimisaenghwalgwa munhwahyŏnsang [Hobby life and cultural phenomena in the laterperiod of the Chosǒn Dynasty]”, Han'gungmunhwa [Hangukmunhwa] 60(2012).

Chang, Chinsǒng (Chang, Chinsung). "Tonggich'anggwa sŏyanggihahak [Dong Qichang and European geometry]", Misulsahakyeongu [Korean journal of art history] 256(2007).

Chin, Chunhyŏn (Jin, Jun-hyeon). "Kŭrimŭl choahan sukchong imgŭm [King Sukjong who loved painting]", 
Seonbimunhwa [Sunbi Culture] 9(2006).

. "Sukchongǔi sŏhwach'wimi [King Sukjong's hobby of calligraphy and painting]", Seouldaehakgyo

Bakmulgwan Yeonbo [Chronological list-Seoul National University Museum] 7, Seouldaehakgyo

Bakmulgwan [Seoul National University Museum](1995).

Cho, Chaehyŏn (Cho, Jaehyeon). Trans. Kyech'ugilgi [Diary Written in the Gye-chuk Year], Seohaemunjip [Bookseapublishing.co], 2003.

Cho, Hyosuk (Cho, Hyo-sook). "Kkotkwa saega kadük'an such'ima-hwajomunsusang [Embroidered Skirt-full of flowers and birds]", Iseungeseoui majimak chijang [The Last Dressing in this World], 2011.

Cho, Insu (Cho Insoo). "Chungguk wŏnmyŏngdaeŭi sahoebyŏndonggwa togyo shinsŏndo [Images of Daoist Immortals in the Yuan and Ming Dynasties]”, Misulsahak [Art History] 23(2009)

Cho, Kyuhǔi (Cho, Kyu Hee). "Mandǔrǒjin myŏngjak-shinsaimdanggwa ch'och'ungdo [The Invention of the Canon: Sinsaimdang (1504-1551) and Insects and Plants]", Misulsawa sigakmunhwa [Art History and Visual Culture] 12(2013).

Chŏng, Chaeryun (Jung, JaeRyun). Translated by Kang, Chuchin (Kang, Jujin), Tongp'yŏngwigongsamun'gyöllok [The Records of Observation and Experience to The public and private of DongPyeongwi], Yangyŏnggak, 1985.

Chŏng, Hyeran. "Junggukhyungbaewa hanGukhyungbaeui bigyogochal [A Study of Korean Rank Badge in comparison with Chinese Rank Badge]", Gomunhwa [KOMUNHWA(Korea Antiquity)] 57(2001).

Chŏng, Min (Jung, Min), “18segi chishiginǔi wanmul ch'wimiwa chijŏk kyŏnghyang [New Trend of intellectual activities in the 18th century]", Gojeonmunhakyeongu [Journal of Korean Classical Literature] 23(2003).

Chŏng, Ǔnim (Jung, Eunim). Inmogwanghuwa Inhyŏnwanghu-munhagŭi ch'angŭro pon chosŏnŭi kungjungmunhwa [Queen Inmok and Inhyeon-Joseon's royal culture as a window of literature 3], Ch'aeryunch'ulp'ansa [chaeryunbook], 2012.

Hong, Kyŏngmo (Hong, Gyeongmo). Saŭidangji - uri chibŭl marhanda : 18segi sadaebugaŭi chugŏ munhwa, I, Jong-muk (Lee, Jongmuk, Trans). Hyumeoniseuteu [humanist], 2009.

Hoang, chŏonghyŏn (Hwang Jeongyeon). "18segi kyŏng hoasachokŭ sŏhoasuchangkoa yesurch'uihyangyumanchyuoa hŭmyŏng [Kyunghwasajok's the Collecting of Paintings and Calligraphic Works and Taste in art in the 18th century]”, Naeirŭr yŏnŭ yŏksa [History that opens tomorrow] 40(2010).

I, Eunha (Lee, Eun Ha). "HwajomunJasuseuranChimawa Chosŏn junggi hwajohwa [Chima Ceremonial Skirt and the paintings of flowers and birds in the mid of Chosun Dynasty]", "The Essential Art of Costum in Joseon Dynasty: Selections from the Donated Collection: The Last Dressing in this World Gyeonggidobakmulgwan [The Gyeonggi Provincial Museum], 2011.

I, Ki (Lee Gi), Songhwajapgi, Hoesangsa, 2000.

I, Kyŏngha (Lee Gyeongha). Trans. 18se-ki yŏ-sŏng saeng-hwal-sa-cha-lyo-chip [18th Century Women's Life History] 2, Bogosa [Bogosa], 2010. 
Kim, Kyŏngmi (Kim, Gyeongmi). Trans. 17se-ki yŏ-sŏng saeng-hwal-sa-cha-lyo-chip [17th Century Women's Life History] 4, Bogosa [Bogosa], 2010.

Kim, Namki (Kim, Namgi). “『Yŏlsŏngŏche』e sillin chosŏn kukwangǔi chehwasi yŏnku [A Study on Kings' poems with pictures of Yulsongoje]", Han'gungmunhangnonch'ong [Thesises on Korean literature] 34(2003).

"Sukchongŭi munyejök kwanshimgwa hanshi segye [A Concerned with literary art and poem of Sukjong]”, Chindanhakpo [The Chin-Tan Society] 98(2004).

Kim, Sangyǒp (Kim, Sangyop). “Gopakyeongcheolssigijeungseohwaryu jeongwanmokrokeul Tonghaebon Dasan Pak, Yeongcheolui Sujanghwaldong [The Life and Art Collection Activities of Pro-Japanese Collaborator Park Yeong-cheol During Japanese Occupation]”, Munhwa [MUNHWAJAE] 44-4(2011).

Pak, Kyeri (Park, Carey). "20segi han'guk'oehwaesoŭu chŏnt'ongnon [(A) study on the twentieth century Korean painters' viewpoints on tradition]”, Ewhayōjadaehakkyo Paksa hagwi nonmun [Ph.D. dissertation at the Ewha Womans University], 2006.

Pak, Kyusu (Park, Gyusu). Geogajapbokgo (Cho Hyosun Trans), Tosǒch'ulp'an sǒkshil, 2000

Sim, Yŏnok (Sim, Yeonok). "Koryŏburhwa suwŏlgwanŭmdoŭi pokshikchingmulgwa munyang [Fabrics and Fabric Motifs Depicted in Goryeo Water-moon Avalokitesvara]”, Misulsahakyǒn'gu [Korean journal of art history] 273(2012).

"Tongadaehakkyo pangmulgwan sojang 〈ch'och'ungdo〉 subyöngŭi chingmulgwa chasu yŏn'gu [Study on Fabric and Embroidery of 〈Embroidered Screen with Grass and Insects〉 Possessed by Dong-A University Museum]”, Munhwajae [Korean Journal of Cultural Heritage Studies] 46-3(2013).

Sŏ, kyŏoghŭi (Seo, Gyeonghui). Trans. 18se-ki yŏ-sŏng saeng-hwal-sa-cha-lyo-chip [18th Century Women's Life History] 6, Bogosa [Bogosa], 2010.

Yang Suchŏng (Yang, sujeang). Chosŏnshidae chasugŭrim yŏn'gu [A Study on Painting of the Joseon Dynasty in the sixteenth and eighteenth centuries], Ewhayöjadaehakkyo Paksa hagwi nonmun [Ph.D. dissertation at the Ewha Womans University], 2016 (a).

. "Chŏn Inhŏnwanghuŭi chasugurrim 〈shinsǒndo〉 yŏn'gu [A Study on The Embroidered picture 〈Painting of Daoist Immortals $\rangle$ presumed to have been produced by Queen InHeon(1578 1626)]”, Tongangmisulsahak [Dongak Art History] 20(2016 (b)).

"Chosŏn 17segi chasugŭrimǔi chŏnsŭnggwa ihaeng [A Study of Transmission and Transition: Embroidered Pictures in 17th Century Joseon]”, Misulsahakpo [Korean Bulletin of Art History] 48(2017).

. "Chosŏn 17segi chasugŭrimŭi ihaenge kwanhan shiron - chŏrirhyungbaerŭl chungshimŭro [A Study on Transition of the Embroidered Painting in 17th Century Joseon]", Tongangmisulsahak [Dongak Art History] 23(2018).

"18segi ihu jasuwa jejakgae gwanhan jaemyeonmo [A Study of Embroidery and the Various Types of Embroiderer in 18th-century Joseon]", Misulsahakpo [Korean Bulletin of Art History] 54(2020). 
. "Chosŏn 17segi such'ǒbŭi munyesajǒk kach'i [The Literary-historical Value of Embroidery Albums in 17th Century Joseon]”, Han'gungminhwa [koreanfolkart] 13(2020).

Wang, Ayong (Wang, Yarong). "Myŏngdae ch'oegoŭi chasuyesul [The Best Embroidery Art of the Ming Dynasty]". Dongasia jasuyesului yeoksa [A History of The East Asia embroidery art], Gukripgogungbakmulgwan [National Palace Museum of Korea], 2013.

\section{Sources in Asia (Chinese, Japanese)}

Cho, P'ung(Zhao, Feng), Chungguksajut'ongsa [(The) general history of Chinese silk], Sojudaehakkyo [Soochow University], 2005.

Dan, Guk-gang (Dan, Guoqiang), “Toŏn-p'ilmukch'wimiyojiksuyesul [Introduction -Fun of Brush and Ink and the Art of Textile Embroidery]”, Chiksusǒhwa [Embroidered Pictures], Sanghaesegich'ulp'an'gobinsayuhan'gongsa (Shanghai Century Publishing (Group) Co., Ltd), 2005.

Kossihwabo [Ku-shih hua-p'o(Mr. Ku Painting Manual)], 1603

Kungnipkogungbangmurwŏn (National Palace Museum), Shipchich'unp'ung [Flight of Fragrance at a Fingertip], Kungnipkogungbangmurwŏn (National Palace Museum), 2015.

Manju gukrip bakmulgwan(Manchoukuo National Museum), Ch'anjoyŏnghwa [TSUAN-TSU-YING-HU], Donggyeong: Jwaubo Gan haenghoe balhaeng (Tokyo: Zauhōkankōkai), 1935.

Sanghae bangmulgwan (Shanghai Museum), Haesanggŭmsu [Fancy Art of Shnghai-Selected works of the Gu's Embroidery], Sanghae bangmulgwan (Shanghai Museum), 2007.

Sŏ, Ulnam (Seo, Ulnam), “Kosugo”, Sŏrisubodosŏl, chungguk'waboch'ulp'ansa (China Pictorial Publishing House), 2004. 


\section{국문초록}

본 연구는 국립중앙박물관에 소장된 〈고사인물도〉에서 보이는 고수(顧繡)의 작풍(作風)을 통해, 조선 후기를 기해 조선에 유입된 고수가 왕실가에서 감상되면서 조선 후기 자수그림의 제작에 있어 어떠한 상관(相關)을 가지고 전개되었는가에 대한 내용이다.

조선 후기에는 사회, 경제, 문화, 규범에 있어 이전과 다른 새로운 양상이 전개되고 있었다. 그중 청조(淸朝)에 대한 우호적인 분위기 속에서 접할 수 있었던 신문물 가운데 중국의 여러 지방수들도 유입되었는데, 그중 고수는 일찍이 왕실 자수의 변화와 제작에 영향을 주고 있었다. 18세기가 되면 자수된 생활용품이 사가, 민가에까지 확장되면서 호사(豪奢)취향으로 유행되었으며, 전문 제작가에 의해 수작(秀作)의 감상용 자수그림이 제작되면서 감상과 소장의 대상으로 수장되기에 이르렀다. 특히 구복(求福)의 대상으로 신선도와 고사인물도를 시수한 감상용 자수그림 병풍이 제작되면서 한아(閒雅)와 숭사(崇奢)의 소재로 문예적 성장이 견인되었다. 이들 자수그림에서 보이는 고수와 상관된 특징으로는 첫째, 고수의 회수에 해당하는 부분을 자리수나 자련수 기법으로 메운 점, 둘째, 고수처럼 공교한 표현의 장식수가 발달했다는 점, 셋째, 고수가 운간을 위해 사용한 푼사를 꼰사로 대체한 점, 넷째, 고수와 달리 모든 도상의 외곽선을 이음수로 둘러 정연함을 강조한 점, 다섯째, 간색(間色)보다는 보색(補色)의 대비를 이용한 점, 여섯째, 요지연도와 같은 자수신선도와 자수고사인물도가 유행한 점 등이다. 이 일련의 상관들은 중국보다 명성이 높았던 조선 자수의 정형적인 작풍으로 발전되었다고 정리할 수 있다. 
Abstract

\title{
The Adoption and Development of the Gu's Embroidery in Late-Joseon embroidery
}

\author{
Yang, sujeang
}

This article uses the idioms of embroidery appreciation as depicted in narrative figure paintings in the collection of the National Museum of Korea, to examine the effects of Gu-style embroidery, which reached Korea during the late Joseon period, on the development of late Joseon embroidered pictures enjoyed by the royal court.

The late Joseon period saw unprecedented developments in social, economic and cultural norms. Among these were friendly relations with Qing, allowing Koreans access to new imported culture including various regional Chinese embroidery styles. Gu embroidery became an early source of influence on change and production of embroidery in the royal court. By the 18th century, embroidered everyday items had spread into the private homes of aristocrats and commoners as part of a luxury trend. Expert producers created masterpieces specifically for viewing, which were collected for this purpose. Decorative embroidered screens were created featuring Taoist hermit and narrative figure paintings, driving artistic growth based on motifs of elegance and appreciation of luxury. Characteristics relating to $\mathrm{Gu}$ found in these works include: first, the filling of parts corresponding to Gu-style mixed embroidery and painting with long and short stitches and irregular long and short stitches; second, the development of a type of decorative stitching capable of the same elaborate expression as $\mathrm{Gu}$; third, the replacement of untwisted thread, in which Gu style was used to achieve gradation, with twisted thread; fourth, the tracing of the outlines of all pictorial elements with outline stitch, unlike in $\mathrm{Gu}$, emphasizing neatness; fifth, the use of contrasting complementary colors rather than intermediate colors; and sixth, the production of Taoist hermit paintings such as Banquet at Jade Pond and narrative figure paintings as screens. In sum, it can be said that this series of phenomena developed into a formal idiom in Joseon embroidery, which had become more highly renowned than that of China by the 19th century.

* Cultural Heritage Connoisseur Office Connoisseur of Cultural Heritage 